LA-14339

Approved for public release;

distribution is unlimited.

2006 LANL Radionuclide Air Emissions Report 
Edited by Hector Hinojosa, Group IRM-CAS

Los Alamos National Laboratory, an Affirmative Action/Equal Opportunity Employer, is operated by Los Alamos National Security, LLC, for the National Nuclear Security Administration of the U.S. Department of Energy under contract DE-AC52-06NA25396.

This report was prepared as an account of work sponsored by an agency of the U.S. Government. Neither Los Alamos National Security, LLC, the U.S. Government nor any agency thereof, nor any of their employees make any warranty, express or implied, or assume any legal liability or responsibility for the accuracy, completeness, or usefulness of any information, apparatus, product, or process disclosed, or represent that its use would not infringe privately owned rights. Reference herein to any specific commercial product, process, or service by trade name, trademark, manufacturer, or otherwise does not necessarily constitute or imply its endorsement, recommendation, or favoring by Los Alamos National Security, LLC, the U.S. Government, or any agency thereof. The views and opinions of authors expressed herein do not necessarily state or reflect those of Los Alamos National Security, LLC, the U.S. Government, or any agency thereof. Los Alamos National Laboratory strongly supports academic freedom and a researcher's right to publish; as an institution, however, the Laboratory does not endorse the viewpoint of a publication or guarantee its technical correctness. 
LA-14339

Issued: June 2007

\section{LANL Radionuclide Air Emissions Report}

David P. Fuehne 



\section{U.S. Department of Energy Report}

\section{LANL Radionuclide Air Emissions}

Site Name: Los Alamos National Laboratory

Location: County of Los Alamos, New Mexico

Operations Office Information:

Office: $\quad$ Los Alamos Site Office

Address: $\quad$ U.S. Department of Energy

National Nuclear Security Administration

Los Alamos Site Office

Los Alamos, NM 87544

Contact: Steve Fong $\quad$ Phone: (505) 665-5534

Site Information:

Operator: Los Alamos National Security, LLC

Address: $\quad$ Los Alamos National Laboratory

PO Box 1663

Los Alamos, NM 87545

Contact: David Fuehne Phone: (505) 665-8855

\section{Compliance Assessment:}

2006 EDE: $\quad 0.47$ mrem 
Page vi 


\section{Executive Summary}

This report describes the impacts from emissions of radionuclides at Los Alamos National Laboratory (LANL) for calendar year 2006. This report fulfills the requirements established by the Radionuclide National Emissions Standards for Hazardous Air Pollutants (Rad-NESHAP). This report is prepared by LANL's RadNESHAP compliance team, part of the Environmental Protection Division. The information in this report is required under the Clean Air Act and is being reported to the U.S. Environmental Protection Agency (EPA). The highest effective dose equivalent (EDE) to an off-site member of the public was calculated using procedures specified by the EPA and described in this report. LANL's EDE was $0.47 \mathrm{mrem}$ for 2006 . The annual limit established by the EPA is 10 mrem per year.

During calendar year 2006, LANL continuously monitored radionuclide emissions at 28 release points, or stacks. The Laboratory estimates emissions from an additional 58 release points using radionuclide usage source terms. Also, LANL uses a network of air samplers around the Laboratory perimeter to monitor ambient airborne levels of radionuclides. To provide data for dispersion modeling and dose assessment, LANL maintains and operates meteorological monitoring systems. From these measurement systems, a comprehensive evaluation is conducted to calculate the EDE for the Laboratory.

The EDE is evaluated as any member of the public at any off-site location where there is a residence, school, business, or office. In 2006, this location was the Los Alamos Airport Terminal. The majority of this dose is due to ambient air sampling of plutonium emitted from 2006 clean-up activities at an environmental restoration site (73-002-99; ash pile). Doses reported to the EPA for the past 10 years are shown in Table E1.

Table E1. Ten-Year Summary of Rad-NESHAP Dose Assessment for LANL

\begin{tabular}{ccc} 
Year & $\begin{array}{c}\text { EDE } \\
(\mathbf{m r e m})\end{array}$ & Highest EDE Location \\
\hline 1997 & 3.51 & 2470 East Gate Dr. \\
1998 & 1.72 & 2470 East Gate Dr. \\
1999 & 0.32 & County Landfill Office \\
2000 & 0.64 & 2470 East Gate Dr. \\
2001 & 1.84 & 2470 East Gate Dr. \\
2002 & 1.69 & 2470 East Gate Dr. \\
2003 & 0.65 & 2470 East Gate Dr. \\
2004 & 1.68 & 2470 East Gate Dr. \\
2005 & 6.46 & 2470 East Gate Dr. \\
2006 & 0.47 & Los Alamos Airport Terminal \\
\hline
\end{tabular}




\section{Events}

In 2006, the Laboratory's AIRNET ambient air monitoring network stations located on site at MDA G detected elevated levels of tritium. MDA G is the Laboratory's waste disposal area. The tritium was found to be coming from a canister that had been brought from clean-up work at a decommissioned tritium facility at Technical Area (TA) 21. Off-site AIRNET stations located in public receptor areas (residence, school, business, or office) for compliance determination did not measure this elevated source release so no dose impacts were calculated. The tritium source was eventually moved to the tritium shafts located at MDA G.

Two continuously monitored stack systems were discontinued in September of 2006. Operations that emit radionuclides from these facilities were suspended and the source term removed. These facilities were located at TA-21, Buildings 155 and 209 and are currently planned for decontamination and demolition. Residual emissions from these facilities will continue to be assessed in a conservative manner until the buildings are actually removed. ${ }^{1}$

New stack monitoring equipment was installed at TA-55, Building PF-4. The original monitoring systems required cleaning or replacement under the Rad-NESHAP maintenance and inspection criteria effective in 2003 . In order to duplicate the sampling profile in the old samplers, yet incorporate more effective technology, four independent samplers were installed in each PF-4 stack. Measured emissions from these four samplers are averaged to determine total stack emissions. The long-term goal for emissions monitoring at TA-55 involves an upgrade of the stack monitoring systems to single-point shrouded probes.

During roofing work on TA-48, Building 1 in early November 2006, the access ladder for stack 48000160 (ES-60) was moved. A severe windstorm occurred that night, and the ladder was blown off the roof and damaged to the point where it was deemed unsafe to re-install. Delays in work scheduling and coordination prevented replacement of the ladder until April 2007. As a result, it was impossible to access the monitoring system for stack 48000160 (ES-60) after November 9 through the end of the reporting year. This resulted in an operational "up-time" of $88.2 \%$ for the 2006 reporting year. The sum of the measured weekly emissions values through November 9 was scaled up by this up-time amount to reflect potential missed emissions from this source. One mitigating factor is that this source does not meet the $0.1 \mathrm{mrem} /$ year off-site dose threshold, which requires continuous monitoring; monitoring at this source is for anticipated elevated operational levels in 2007. Therefore, the system down time in 2006 does not result in a compliance situation for the Laboratory. 


\title{
2006 LANL Radionuclide Air Emissions Report
}

by

\author{
David P. Fuehne
}

\begin{abstract}
The emissions of radionuclides from Department of Energy Facilities such as Los Alamos National Laboratory (LANL) are regulated by the Amendments to the Clean Air Act of 1990, National Emissions Standards for Hazardous Air Pollutants (40 CFR 61Subpart H). These regulations established an annual dose limit of 10 mrem to the maximally exposed member of the public attributable to emissions of radionuclides. This document describes the emissions of radionuclides from LANL and the dose calculations resulting from these emissions for calendar year 2006. This report meets the reporting requirements established in the regulations.
\end{abstract}

\section{Section I. Facility Information}

\subsection{4(b)(1) Name and Location of Facility}

Los Alamos National Laboratory (LANL or the Laboratory) and the associated residential areas of Los Alamos and White Rock are located in Los Alamos County in north-central New Mexico, approximately $100 \mathrm{~km}$ (60 mi) north-northeast of Albuquerque and $40 \mathrm{~km}(25 \mathrm{mi})$ northwest of Santa Fe, (Figure 1).

\subsection{4(b)(2) List of Radioactive Materials Used at LANL}

Since the Laboratory's inception in 1943, its primary mission has been nuclear weapons research and development. Programs include weapons development, nonproliferation, magnetic and inertial fusion, nuclear fission, nuclear safeguards and security, and laser isotope separation. There is also basic research in the areas of physics, chemistry, engineering, and biology.

The primary facilities involved in the emissions of radioactivity are outlined in this section. The facility locations are designated by technical area (Figure 2) and building. For example, the facility designation TA-3-29 is Building 29 at Technical Area (TA) 3. Potential radionuclide release points are listed in several tables that follow. Some of the sources described below are characterized as non-point. Off-site impacts resulting from diffuse and fugitive emissions of radioactive particles and tritium oxide (HTO) from non-point sources are calculated using LANL's air sampling network (AIRNET).

Radioactive materials used at LANL include weapons-grade plutonium, heat-source plutonium, enriched uranium, depleted uranium, and tritium. Also, a variety of materials are generated through the process of activation; consequent emissions occur as gaseous mixed activation products (GMAP) and other activation products occur in particulate and vapor form (P/VAP). 


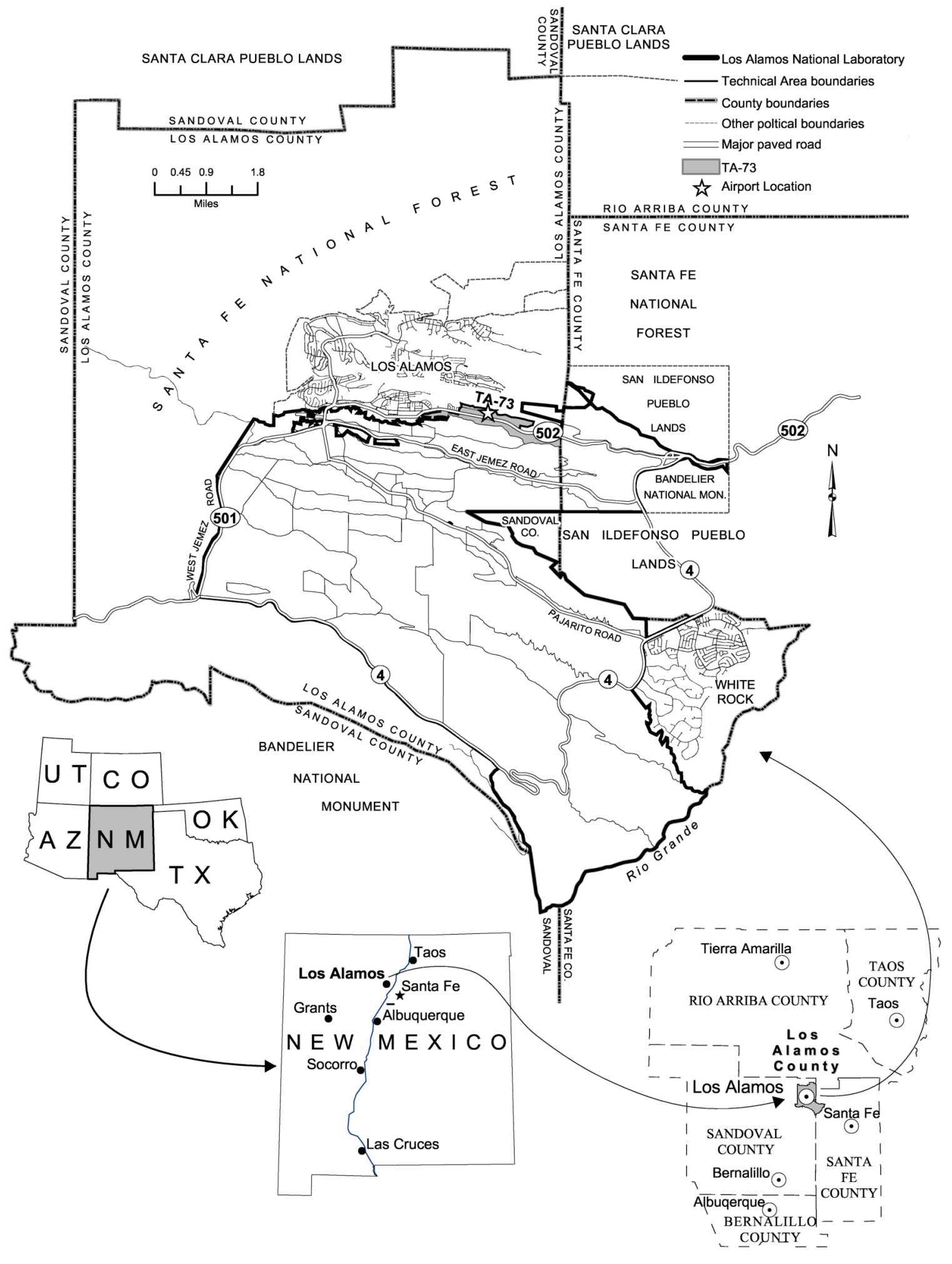

Figure 1. Location of Los Alamos National Laboratory. 


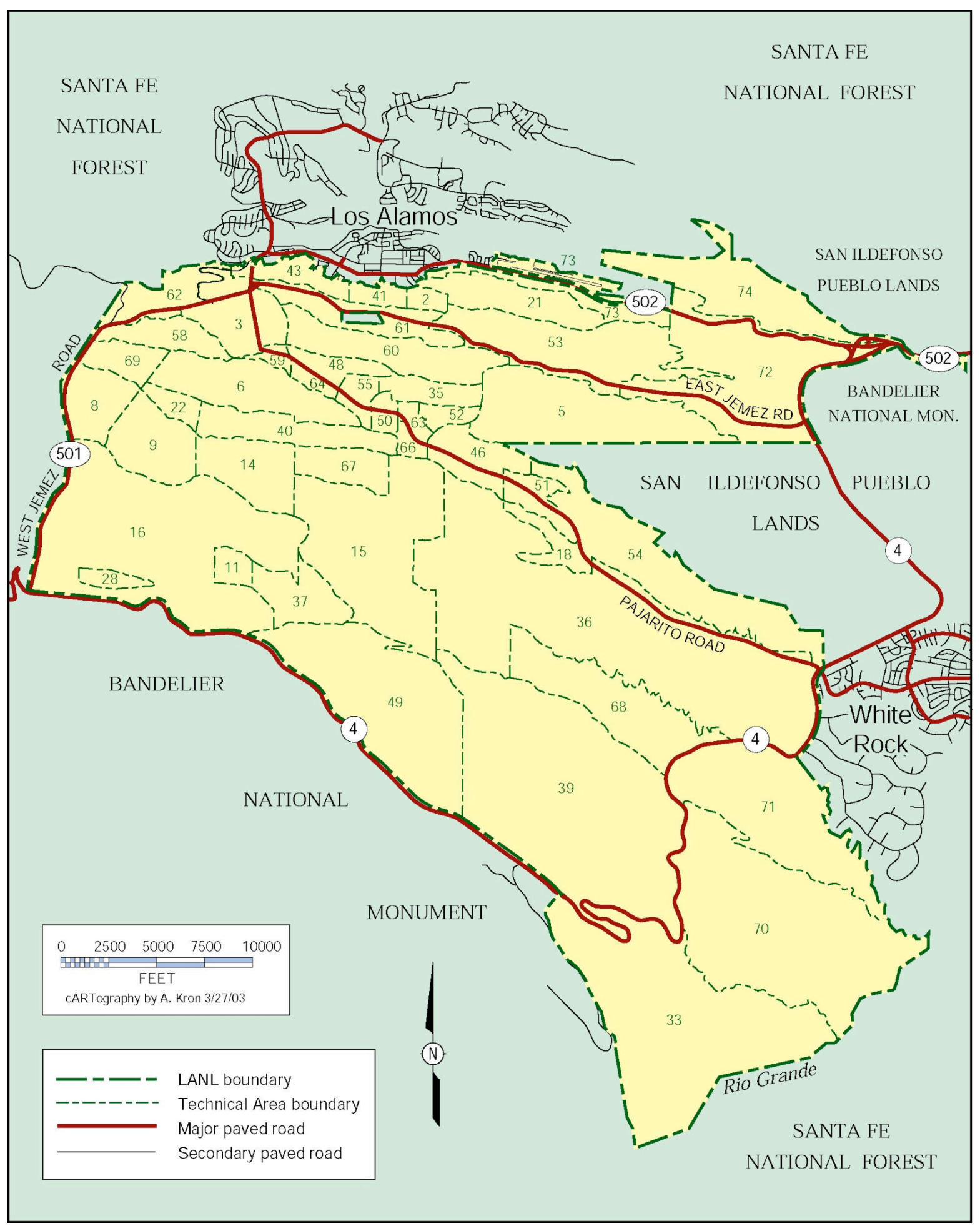

Figure 2. Los Alamos National Laboratory technical areas by number. 


\section{LANL Radionuclide Air Emissions Report}

The radionuclides emitted from point sources at LANL in calendar year 2006 are listed in the subsequent tables. Tritium is released as HTO and elemental tritium (HT). Plutonium contains traces of ${ }^{241} \mathrm{Am}$, a transformation product of ${ }^{241} \mathrm{Pu}$. Some of the uranium emissions are from open-air explosive tests involving depleted uranium. GMAP emissions include ${ }^{41} \mathrm{Ar},{ }^{11} \mathrm{C},{ }^{13} \mathrm{~N},{ }^{14} \mathrm{O}$, and ${ }^{15} \mathrm{O}$. Various radionuclides such as ${ }^{197 \mathrm{~m}} \mathrm{Hg}$,

${ }^{68} \mathrm{Ge}$, and ${ }^{76} \mathrm{Br}$ make up the majority of the P/VAP emissions.

\subsection{4(b)(3) Handling and Processing of Radioactive Materials at LANL Technical Areas}

Additional descriptions of LANL technical areas can be found in the Annual Environmental Surveillance Report for LANL. ${ }^{2}$ More thorough descriptions of LANL operations can be found in the Annual SWEIS Yearbooks, the most recent being published in $2006 .^{3}$

The primary facilities responsible for radiological airborne emissions are as follows.

TA-3-29: The Chemistry and Metallurgy Research (CMR) facility conducts chemical and metallurgical research. The principal radionuclides used are isotopes of plutonium as well as other actinides. There are a variety of activities involving plutonium and uranium, which support many LANL and other U.S. Department of Energy (DOE) programs.

TA-3-66: This facility is used for a variety of nuclear materials work, primarily for dealing with metallic and ceramic items, including depleted uranium.

TA-3-102: This machine shop is used for the metalworking of radioactive materials, primarily depleted uranium.

TA-3-1698: This facility is designated as the Materials Science Laboratory. The building was designed to accommodate a wide variety of chemicals used in small amounts that are typical of many university and industrial labs conducting research in materials science.

TA-15 and TA-36: These facilities conduct open-air explosive tests involving depleted uranium and weapons development testing.

TA-15-312—Dual-Axis Radiographic Hydrodynamic Test Facility: This facility conducts highexplosive-driven experiments to investigate weapons functions and behavior during nonnuclear tests using advanced radiography.

TA-16-205-Weapons Engineering Tritium Facility (WETF): This facility is located in Buildings 205 and 205A in the southeast section of TA-16. Building 205 was specifically designed and built to process tritium safely. The operations at WETF are divided into two categories: tritium processing and activities that support tritium processing. Examples of tritium-processing operations include the repackaging of tritium into smaller quantities and the packaging of tritium and other gases to user-specified pressures. Other operations include reacting tritium with other materials to form compounds and analyzing the effects of tritium.

TA-21: Many of the facilities at this decommissioned radiochemistry site are undergoing decontamination and demolition (D\&D). Some of these operations may contribute to diffuse emissions of uranium and plutonium into the air. 


\section{LANL Radionuclide Air Emissions Report}

TA-21-155 and TA-21-209: These facilities, located in the DP East area, have historically conducted operations involving tritium but are currently being prepared for D\&D. Programs included the testing of tritiumcontrol systems for the nuclear fusion program, the preparation of targets containing tritium for laser-fusion research, and the handling of tritium for defense programs. During 2006, the source term was removed from these buildings. In September of 2006, stack monitoring activities were discontinued.

TA-18: Historically, this nuclear facility studied the behavior of nuclear materials using critical assemblies. Operations that had the potential to emit radionuclides did not occur in 2006 and no future operations that emit radionuclides from this site are planned.

TA-41-4: This building was formerly used as a tritium-handling facility. The tritium sources were removed in 2002. Diffuse tritium emissions could result from residual tritium contamination and cleanup operations.

TA-48-1: The principal activities carried out in this facility are radiochemical separations supporting the medical radioisotope production program, the Yucca Mountain program, nuclear chemistry experiments, and geochemical and environmental research. These separations involve $\mathrm{nCi}$ to $\mathrm{Ci}$ (hot cell) amounts of radioactive materials and use a wide range of analytical chemical separation techniques, such as ion exchange, solvent extraction, mass spectroscopy, plasma emission spectroscopy, and ion chromatography.

TA-50-1: This waste management site consists of an industrial low-level (radioactive) liquid waste treatment plant.

TA-50-37: Currently there are no operations involving radioactive material in this building; future operations may involve the use of radioactive actinides.

TA-50-69: This waste management site consists of a waste characterization, reduction, and repackaging facility.

TA-53: This technical area houses the Los Alamos Neutron Science Center (LANSCE), a linear particle accelerator complex. The accelerator is used to conduct research in stockpile stewardship, radiobiology, materials science, and isotope production, among other areas. LANSCE consists of the Manuel Lujan Neutron Scattering Center, the Proton Storage Ring (PSR), the Weapons Neutron Research facilities, the Proton Radiography facility, and the high-intensity beam line (Line A). The facility accelerates protons and $\mathrm{H}$ - ions to an energy of $800 \mathrm{MeV}$ into target materials such as graphite and tungsten to produce neutrons and other subatomic particles. The design current of the accelerator is approximately 1000 microamperes. Medium (120 microamps) intensity beam operations to the PSR and the Manuel Lujan Neutron Scattering Center were conducted in April through December 2006. Low-intensity beam (up to 10 microamps) operations to the PSR, the Weapons Neutron Research facility, and the Proton Radiography facility were conducted throughout the same period. Airborne radioactive emissions result from proton beams and secondary particles passing through and activating air in target cells, beam stop, and surrounding areas, or activating water used in target cooling systems. The majority of the emissions are short-lived activation products such as ${ }^{11} \mathrm{C},{ }^{13} \mathrm{~N}$, and ${ }^{15} \mathrm{O}$. Most of the activated air is vented through the main stacks; however, a fraction of the activated air becomes a fugitive emission from the target areas. Two solar evaporative basins were 


\section{LANL Radionuclide Air Emissions Report}

constructed and began operation in 1999 to evaporate wastewater from the accelerator. Evaporation of water from these facilities can result in a diffuse source of airborne tritium.

TA-54: This waste management site consists of active and inactive shallow land burial sites for solid waste and is the primary storage area for mixed and transuranic radioactive waste. MDA G at TA-54 is a known source of diffuse emissions of tritium vapor. Resuspension of soil contaminated with low levels of plutonium/americium has also created a diffuse source. Shipments of transuranic waste for disposal at the Waste Isolation Pilot Plant began in 1999.

TA-55-4: This facility provides a pit production capability and continues the role providing the capability for research-and-development applications in chemical and metallurgical processes for recovering, purifying, and converting plutonium and other actinides. ${ }^{4}$ A wide range of activities (e.g., the heating, dissolution, forming, and welding, of special nuclear materials) is also conducted. Additional activities include investigating the means to safely ship, receive, handle, and store nuclear materials and to manage wastes and residues from TA-55. Limitedscope tritium operations also take place in certain areas of TA-55.

\section{Section II. Air Emissions Data}

\subsection{4(b)(4) Point Sources}

Monitored and unmonitored release points at LANL are listed in Table 1. The point sources are identified using an eight-digit identification number for each exhaust stack (StackID); the first two digits represent the LANL technical area, the next four the building, and the last two digits the stack number. Also listed in Table 1 are type, number, and efficiency of the effluent controls used on the release points. Each stage of the high-efficiency particulate air (HEPA) exhaust filters is tested at least once every 12 months. The performance criteria for HEPA filter systems are a maximum penetration of $5 \times 10^{-4}$ for one stage and $2.5 \times 10^{-7}$ for two stages in series, in which penetration equals the concentration of aerosol downstream of the air cleaner divided by concentration upstream.

In addition to the 28 monitored point sources, 58 unmonitored release points in more than 30 LANL buildings are included in Table 1. Under 40 CFR 61.93(b)(4)(i), sampling of these release points is not required because each release point has a potential effective dose equivalent (PEDE) of less than $0.1 \mathrm{mrem} / \mathrm{yr}$ at the critical receptor. However, in order to verify that emissions from unmonitored point sources remain low, LANL conducts periodic confirmatory measurements in the form of the 2006 Radioactive Materials Usage Survey for Unmonitored

Tier III Point Sources. ${ }^{5}$ The purpose of this survey is to collect and analyze radioactive materials usage and process information for the monitored and unmonitored point sources at LANL.

The distance between each of the release points and the nearest receptor is provided in Table 1 . The nearest receptor can be a residence, school, business, or office. In this report, the nearest receptor is defined as the public receptor most impacted by a given release point; that is, the air dispersion pattern is taken into account to determine the nearest or most critical receptor location.

In compliance with Appendix D to 40 CFR 61, we have used data collected from the facilities in conjunction with engineering calculations and other methods to develop conservative emissions estimates from 


\section{LANL Radionuclide Air Emissions Report}

unmonitored point sources. Estimated PEDEs are calculated by modeling these emissions estimates using the U.S. Environmental Protection Agency (EPA)-approved CAP88 dose modeling software. A comprehensive survey of all of LANL's monitored and unmonitored point sources is conducted annually or biannually, depending on the magnitude of potential emissions and are presented in the 2006 Radioactive Materials Usage Survey for Unmonitored Tier III Point Sources. ${ }^{5}$ The Laboratory has established administrative requirements to evaluate all potentially new sources. These requirements are established for the review of new Laboratory activities and projects, ensuring that air quality regulatory requirements will be met before the activity or project begins. ${ }^{6}$

\section{Non-point Sources}

There are a variety of non-point sources within the $111 \mathrm{~km}^{2}$ of land occupied by LANL. Non-point sources can occur as diffuse or large-area sources or as leaks or fugitive emissions from facilities. Examples of non-point sources of airborne radionuclides include surface impoundments, shallow land burial sites, open burn sites, live firing sites, outfalls, container storage areas, unvented buildings, waste treatment areas, solid waste management units, and tanks. The Laboratory measures the annual average ambient concentrations of important airborne radionuclides (other than activated gases) at a number of potential receptor locations.

LANL summarizes the potential impacts of non-point sources by analyzing and reporting air concentration measurements collected at ambient air-sampling (AIRNET) sites around the Laboratory. The Laboratory and EPA negotiated this method of assessing non-point sources as part of a Federal Facility Compliance Agreement. ${ }^{7}$ Results of the air sampling analysis are provided in Section III of this report. There were no unusual results recorded by the air sampling stations for 2006 .

\section{Radionuclide Emissions}

Radionuclides released from monitored point sources, along with the annual emissions for each radionuclide, are documented in Table 2 . The point sources are identified using an eight-digit identification number for each exhaust stack: the first two digits represent the LANL technical area, the next four digits the building, and the last two digits the stack number. No detectable emissions are denoted as "none." A map showing the general locations of the facilities continuously monitored for radionuclide emissions is shown in Figure 3.

\section{Pollution Controls}

The most common type of filtration for emission control purposes at LANL is the HEPA filter, as noted in

Table 1. HEPA filters are constructed of submicrometer glass fibers that are pressed and glued into a compact, paper-like, pleated media. The media are folded alternately over corrugated separators and mounted into a metal or wood frame in eight standard sizes and airflow capacities. A Type I nuclear-grade HEPA filter is capable of removing $99.97 \%$ of $0.3-\mu \mathrm{m}$ particles at rated airflow. Other types of filters used in ventilation systems are Aerosol 95; RIGA-Flow 220, 221, and 222; and FARR 30/30. These units are typically used as prefilters in HEPA filtration systems. These filters are significantly less efficient than HEPA filters and are typically used for collecting 


\section{LANL Radionuclide Air Emissions Report}

This page has been removed for operational security reasons. Please contact the Ecology and Air Quality Group at (505) 665-8855 for a hard copy of the locations of facilities with continuously operated stack-sampling systems for radionuclide emissions.

Figure 3. Location of facilities with continuously operated stack-sampling systems for radionuclide emissions. 


\section{LANL Radionuclide Air Emissions Report}

particulate matter larger than $5 \mu \mathrm{m}$. The above-mentioned filters are only effective for particles. When the contaminant of concern is in the form of a gas, activated charcoal beds are used. Charcoal beds collect the gas contaminant through an adsorption process in which the gas comes in contact with the charcoal and adheres to the surface of the charcoal. The charcoal can be coated with different types of materials to make the adsorption process more efficient for different types of contaminants. Typically, charcoal beds achieve an efficiency of $98 \%$ capture.

Tritium effluent controls are generally composed of a catalytic reactor and a molecular sieve bed. Tritiumcontaminated effluent is passed through a catalyst that converts HT into HTO. This HTO is then collected as water on a molecular sieve bed. This process can be repeated until the tritium level is at, or below, the desired level. The effluent is then vented through the stack.

A delay system is used to reduce some of the short-lived radionuclides generated by activation at LANSCE. Emissions from the highest source of activated gas (the off-gas system for the 1L target cooling loops) are directed into a long transport line to hold up the radionuclide gases before emission. This delay system is used to provide a reduction in radionuclide emissions from the $1 \mathrm{~L}$ target area.

\section{Compliance with New Maintenance and Inspection Requirements under the Revised Rad-NESHAP}

The 2003 revisions to Subpart H established several new inspection and maintenance requirements for monitored stacks. These requirements are based on American National Standards Institute/Health Physics Society N13.1-1999, Sampling and Monitoring Releases of Airborne Radioactive Substances from the Stacks and Ducts of Nuclear Facilities. Annual visual inspection of monitoring systems is a component of the Laboratory's program to comply with these new requirements. In 2006, 25 stack sampling systems were inspected around the Laboratory. These systems were subjected to internal and external inspections using a borescope. Three newly installed systems were not inspected because they went into service during the 2006 reporting year. Ten inspected stack sampling systems were cleaned under the regulation because of discrete particles in certain nozzles or dust buildup on exterior surfaces. In 2006, no radiological material was measured on inspection equipment or cleaning equipment.

Therefore, no additions to the source term are required from this pathway for 2006.

\section{Section III. Dose Assessment}

\subsection{4(b)(7) Description of Dose Calculations}

EDE (or dose) calculations for point sources, unmonitored point sources, and non-point gaseous activation products from LANSCE were performed with the CAP88 code. Verification of the CAP88 code is performed by running the EPA test case.

\section{Development of Source Term}

\section{Tritium emissions}

Tritium emissions from the Laboratory's tritium facilities are measured using a collection device known as a bubbler. This device enables the Laboratory to determine not only the total amount of tritium released but also 


\section{LANL Radionuclide Air Emissions Report}

whether it is in the elemental (HT) or oxide (HTO) form. The bubbler operates by pulling a continuous sample of air from the stack, which is then "bubbled" through three sequential vials containing ethylene glycol. The ethylene glycol collects the water vapor from the sample of air, including any tritium that is part of a water molecule (tritium oxide, or HTO). After bubbling through these three vials, essentially all the HTO is removed from the air, leaving elemental tritium, or HT. The sample, containing the HT, is then passed through a palladium catalyst that converts the HT to HTO. The sample is pulled through three additional vials containing ethylene glycol, which collects the newly formed HTO. The amount of HTO and HT is determined by analyzing the ethylene glycol for the presence of tritium using liquid scintillation counting. Although LANL's measurement device can distinguish the presence of HTO from HT, all emissions of tritium are assumed to be HTO for modeling the off-site dose. Because HTO contributes approximately 20,000 times more dose than an equivalent amount of HT, this is a conservative measure, further ensuring that the dose to an off-site receptor is not underestimated.

Tritium emissions from LANSCE do not require monitoring under 40 CFR 61.93(b)(4)(i). The primary source for airborne tritium emissions at LANSCE is activation of water vapor in air and activation and subsequent evaporation of water in the cooling system of beam targets. Because of the low relative contribution of tritium to the off-site dose at LANSCE, formal monitoring for tritium was discontinued after July 2001. However, the tritium emissions for 2006 can be calculated based on the rate of generation measured in 2001. Using these rate-ofgeneration calculations, the tritium emissions from LANSCE stacks in 2006 were calculated to be about 9 Ci.

\section{Radioactive particle emissions}

Emissions of radioactive particulate matter, generated by operations at facilities such as the CMR facility (TA-3-29) and the Plutonium Facility (TA-55), are sampled using a glass-fiber filter. A continuous sample of stack air is pulled through the filter, where small particles of radioactive material are captured. These samples are analyzed weekly using gross alpha/beta counting and gamma spectroscopy to identify any increase in emissions and to identify short-lived radioactive materials. Every six months, LANL composites these stack samples for subsequent analysis at an off-site laboratory. These composite samples are analyzed to determine the total activity of materials such as ${ }^{234} \mathrm{U},{ }^{235} \mathrm{U},{ }^{238} \mathrm{U},{ }^{238} \mathrm{Pu},{ }^{239} \mathrm{Pu}$, and ${ }^{241} \mathrm{Am}$. These data are then combined with estimates of sampling losses and stack and sample flows to calculate emissions. For the case of radionuclides that have shortlived daughters, LANL includes these progeny in the source term.

\section{Vapor form emissions}

Vapor emissions, generated by LANSCE operations and by hot-cell activities at TA-3-29 and TA-48, are sampled using a charcoal filter or canister. A continuous sample of stack air is pulled through a charcoal filter upon which vaporous emissions of radionuclides are adsorbed. The amount and identity of the radionuclide(s) present on the filter are determined through the use of gamma spectroscopy. This information is then used to calculate emissions. Examples of radionuclides of this type include ${ }^{68} \mathrm{Ge}$ and ${ }^{76} \mathrm{Br}$. 


\section{LANL Radionuclide Air Emissions Report}

\section{Gaseous mixed activation products (GMAP)}

GMAP emissions resulting from activities at LANSCE are measured using near-real-time monitoring data. A sample of stack air is pulled through an ionization chamber that measures the total amount of radioactivity in the sample. Specific radioisotopes are identified through the use of gamma spectroscopy and decay curves. This information is then used to calculate emissions. Radionuclides of this type include ${ }^{11} \mathrm{C},{ }^{13} \mathrm{~N}$, and ${ }^{15} \mathrm{O}$.

\section{Summary of Input Parameters}

EDE to potential receptors was calculated for all radioactive air emissions from sampled LANL point sources. Input parameters for these point sources are provided in Table 3. The geographic locations of the release points, given in New Mexico State Plane coordinates, are provided in Table 4. The relationships of receptor locations to the individual release points are provided in Table 5. The nearest receptor location is different for each point source. Other site-specific parameters and the sources of these data are provided in Table 6.

LANL operates an on-site network of meteorological monitoring towers. Data gathered by the towers are summarized and formatted for input to the CAP88 program. For 2006, data from two different towers were used for the air-dispersion modeling; the tower data that is most representative of the release point is applied. Copies of the meteorological data files used for the 2006 dose assessment are provided in Table 7.

The Laboratory also inputs population array data to the CAP88 program. The data file represents a 16sector polar-type array, with 20 radial distances for each sector. Population arrays are developed for each release point using U.S. Census data, updated with annual projections from the New Mexico Bureau of Business and Economic Research. An example of the population array used for the LANSCE facility is provided in Table 8. For agricultural array input, LANL is currently using the default values in CAP88. Finally, the radionuclide inputs for the point sources monitored in 2006 are provided in Table 2.

\section{Public Receptors}

Compliance with the annual dose standard is determined by calculating the highest EDE to any member of the public at any off-site point where there is a residence, school, business, or office. The Laboratory routinely evaluates public areas to assure that any new residence, school, business, or office is identified for the EDE calculation. As per EPA guidance, ${ }^{8}$ personnel that work in leased space within the boundaries of the Laboratory are not considered members of the public for the EDE determination. Personnel of this type are considered to be subcontractors to DOE, similar to security guards and maintenance workers.

\section{Point Source Emissions Modeling}

The CAP88 version 3 program was used to calculate doses from both the monitored and unmonitored point sources at LANL. The CAP88 program uses on-site meteorological data to calculate atmospheric dispersion and transport of the radioactive effluents. CAP88 includes all radionuclides for which there are dose conversion factors

in the EPA's Federal Guidance Reports. ${ }^{9}{ }^{9} 10,11$ In 2006, only two monitored radionuclides were not included in CAP88: ${ }^{10} \mathrm{C}$ and ${ }^{14} \mathrm{O}$. For these, ${ }^{11} \mathrm{C}$ was used as a surrogate, as described in the Laboratory procedure ENV-EAQ- 


\section{LANL Radionuclide Air Emissions Report}

512. ${ }^{12}$ CAP88 was used to calculate the ${ }^{11} \mathrm{C}$ dose, which was then adjusted for the number of curies emitted, the gamma energy emitted per decay, and the half life of the radionuclides. The maximum dose from emissions of radionuclides not included in the CAP 88 library was $3.8 \mathrm{E}-6 \mathrm{mrem}$. This dose contribution is well below the criteria for individual nuclide monitoring, which is $10 \%$ of a source's PEDE.

\section{LANSCE Fugitive Emission Modeling}

Some of the GMAP created at the accelerator target cells or at other accelerator beam line locations migrate into room air and into the environment. These fugitive sources are continuously monitored throughout the beamoperating period. ${ }^{13}$ In 2006, approximately $151 \mathrm{Ci}$ of ${ }^{11} \mathrm{C}$ and $6 \mathrm{Ci}$ of ${ }^{41} \mathrm{Ar}$ were released from LANSCE as fugitive emissions. These sources were modeled as area sources using CAP88. Fugitive effluents were modeled from two areas at LANSCE; the additional source information is provided in Table 9.

Other fugitive emissions were reported in this table in recent years, including emissions from the LANSCE Isotope Production Facility at TA-53, Building 984, criticality experiments at TA-18, and non-point releases from TA-49 and TA-46. These emissions are not reported for 2006. Emissions from the Isotope Production Facility are exhausted through stacks, so this facility was transferred to the non-monitored stacks program for 2006. The off-site dose from this facility is included in the total of the non-monitored point sources. Criticality experiments at TA-18 have ceased, so that source no longer needs reporting. And the fugitive emissions reported in 2005 from TA- 49 and TA-46 were one-time events in 2005, so there are no emissions from them in 2006.

\section{Environmental Data Used for Non-point Source Emission Estimation}

The net annual average ambient concentration of airborne radionuclides measured at 19 air sampling stations (Figure 4) is calculated by subtracting an appropriate background concentration value. The net concentration at each air sampler is converted to the annual EDE using Table 2 of Appendix E of 40 CFR 61 and applying the valid assumption that each table value is equivalent to $10 \mathrm{mrem} / \mathrm{yr}$ from all appropriate exposure pathways (100\% occupancy assumed at the respective location). ${ }^{14}$ Dose assessment results from each air sampler are given in Table 10. The operational performance and analytical completeness of each air sampler is provided in Table 11.

\section{LANSCE Monthly Assessments}

The Laboratory evaluates and reports the dose from short-lived radioactive gases released from LANSCE on a monthly basis. The monthly dose values are evaluated with the actual meteorology for the month and these doses are shown in Table 12. For 2006 the Laboratory also evaluated the total LANSCE emissions for the year and compared the results to the monthly values summed for the calendar year; the values for these two assessments were 0.176 and 0.173 mrem, respectively, at East Gate; both results were $0.015 \mathrm{mrem}$ at the Airport Terminal. The values show satisfactory agreement. We used the larger value. 


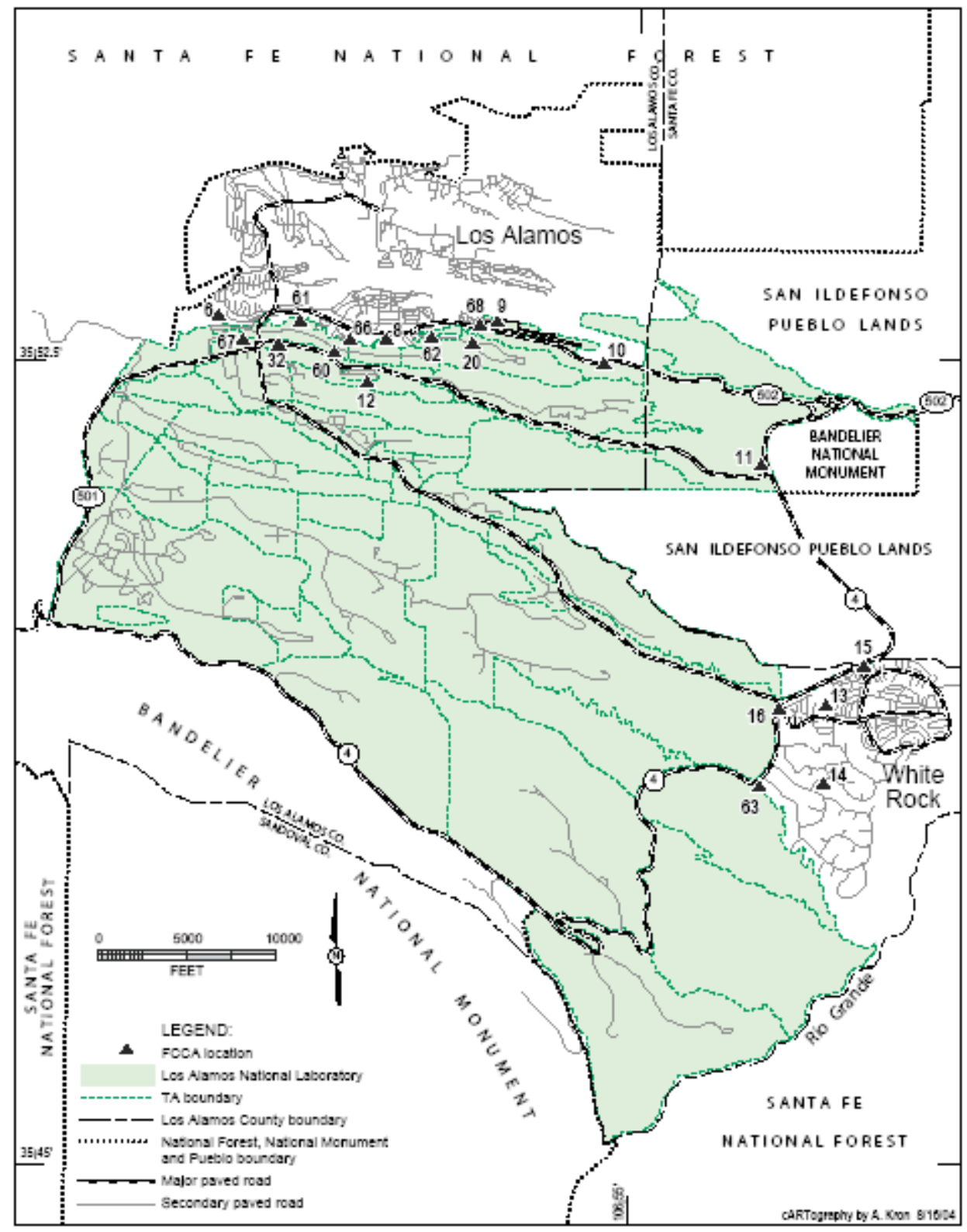

Figure 4. Locations of air sampling stations used for non-point source emissions compliance. 


\section{LANL Radionuclide Air Emissions Report}

\section{Highest EDE Determination}

For the past six years, the maximally exposed individual (MEI) location has been at 2470 East Road, usually referred to as "East Gate." The dose was mostly a result of LANSCE emissions. Because the LANSCE emissions for 2006 were reduced, the location of the 2006 MEI was not as readily apparent as in the past and required more detailed calculations, as follows. To determine the MEI location, we considered all locations with an AIRNET dose greater than that at East Gate. (Refer to Table 10 for the AIRNET doses.) The locations considered were TA-21 MDA B (0.42 mrem), Los Alamos Airport Terminal (0.22 mrem), Los Alamos County Landfill (0.10 mrem), Los Alamos Inn South (0.09 mrem), Crossroads Bible Church (0.05 mrem), and Los Alamos Airport Road (0.05 mrem). The 0.42-mrem value measured near TA-21 MDA B was the result of remediation work at MDA V, which is immediately adjacent to the TA-21 AIRNET station. There is no NESHAP receptor at this location. The location of the highest public receptor dose from the MDA V work is at Airport Road, where the dose is $1 / 8$ of the value at TA-21 MDA B. This difference in dose is expected because the distance from this AIRNET station to the source at MDA V is about 10 times as great. The dose at the Los Alamos Airport Terminal is larger than at Airport Road. This dose is a result of remediation work at TA-73, Building 2, immediately adjacent to the AIRNET station and the airport terminal. The stack doses at the airport terminal and Airport Road are similar, so the total at the airport terminal is larger and it is a candidate for the MEI location. At the other locations, the doses from AIRNET are smaller and they are farther from LANSCE, so the total off-site dose total is smaller. Thus, there are two MEI candidates: East Gate and the Los Alamos Airport Terminal. To determine which was the higher, we performed a full set of calculations for both (Table 13) and added the corresponding AIRNET doses. These calculations result in annual dose values of $0.42 \mathrm{mrem}$ at the East Gate location and $0.47 \mathrm{mrem}$ at the Los Alamos Airport Terminal location. The dose at the Los Alamos Airport Terminal was higher so it is the MEI location for 2006 operations.

\subsection{Compliance Assessment}

The highest EDE to any member of the public at any off-site point where there is a residence, school, or business was 0.47 mrem for radionuclides released by LANL in 2006. This dose was calculated by adding up the doses for each of the point sources at LANL, the diffuse and fugitive gaseous activation products from LANSCE, and the dose measured by the ambient air sampler in the vicinity of the public receptor location. The compliance assessment also includes a potential dose contribution of about 0.16 mrem from unmonitored stacks. Because the emissions estimates do not account for pollution control systems, the actual dose will be significantly less for the unmonitored point sources. Also, this dose includes a minor contribution from radionuclides not included in CAP88. Table 13 of this report provides the compliance assessment summary. The location of the off-site point of highest EDE for 2006 was the Los Alamos Airport Terminal Building. 


\section{LANL Radionuclide Air Emissions Report}

\section{Section IV. Construction and Modifications}

\subsection{4(b)(8) Construction, Modifications, and 61.96 Activity Relocations}

A brief description of construction and modifications that were completed and/or reviewed in 2006 but for which the requirement to apply for approval to construct or modify was waived under 61.96 is listed below:

\section{Soil vapor extraction pilot study}

A soil vapor extraction (SVE) pilot study was conducted at TA-54, MDA L, from June 14 through August 9, 2006. Due to the presence of tritium in the soil at MDA L, this was considered a new source of radioactive air emissions. Emissions were conservatively calculated, based on the highest concentration of tritium found in the soil, $100 \%$ release of all tritium, and a full year of around-the-clock operation (8760 hours) of the extraction unit. With these parameters, CAP88 calculated a worst-case uncontrolled dose of less than $0.01 \mathrm{mrem} / \mathrm{y}$ ear. Actual operation time for the SVE system was under 1200 hours. There are no current plans to use SVE at the Laboratory in 2007, although it remains a viable treatment option and could be used in the future.

\section{Fission fragment experiments}

A series of material properties experiments using actinides is being conducted at TA-53, Building 1 . This building is a non-monitored point source, and operations are tracked as part of the Radioactive Materials Usage Survey. These fission fragment experiments began in September 2006 and will continue in 2007 and 2008. They are being conducted as part of the Stockpile Stewardship Program and are considered a new activity at LANL. Emissions were conservatively estimated based on the project's entire operating envelope and the Appendix D release fraction for particulates. Using CAP88 and these parameters, the uncontrolled dose was estimated to be 2E-3 $\mathrm{mrem} / \mathrm{yr}$. Based on actual material usage in 2006, potential emissions from actual operations were estimated at $4.5 \mathrm{E}-4 \mathrm{mrem} / \mathrm{yr}$.

\section{Kratos instrument}

In 2006, the Kratos Axis-Ultra instrument was used to look at tritium-contaminated samples at TA-16, Building 450. The Kratos is a multi-technique instrument used for surface and interface studies. These studies are part of an existing, ongoing research program at LANL. This activity represents the first time radioactive material was used in TA-16-450 with the potential for airborne emissions. This building is a non-monitored point source, and operations are tracked as part of the Radioactive Materials Usage Survey. Dose from the potential worst-case emissions from this activity were estimated to be $8.5 \mathrm{E}-3 \mathrm{mrem} / \mathrm{yr}$. Based on actual material usage in 2006 , the potential dose was 3.0E-7 mrem/yr. These studies will continue in 2007.

\section{Section V. Additional Information}

This section is provided pursuant to DOE guidance and is not required by Subpart H reporting requirements. 


\section{LANL Radionuclide Air Emissions Report}

\section{Unplanned Releases}

During 2006, the Laboratory had no instances of increased airborne emissions of radioactive materials that required reporting to the EPA. There were no instances of an unplanned event.

\section{Environmental Monitoring}

An extensive environmental monitoring network is operated at LANL that includes several environmental monitoring stations located near the LANSCE boundary inhabited by the public. Measurement systems at these stations include thermoluminescent dosimeters, continuously operated air samplers, and in-situ high-pressure ion chambers. The combination of these measurement systems allows for monitoring of radionuclide air concentrations and the radiation exposure rate. Results for air sampling are published here; results for all monitoring data are published in the Annual Environmental Surveillance Report for DOE Order compliance.

\section{Other Supplemental Information}

- 80-km collective effective (population) dose equivalent for 2006 airborne releases: 0.6 person-rem

- Compliance with Subparts Q and T of 40 CFR 61-Radon-222 Emissions These regulations apply to ${ }^{222} \mathrm{Rn}$ emissions from DOE storage/disposal facilities that contain by-product material. "By-product material" is the tailings or wastes produced by the extraction or concentration of uranium from ore. Although this regulation targets uranium mills, LANL has likely stored small amounts of by-product material used in experiments in the TA-54 low-level waste facility, MDA G; this practice makes the Laboratory subject to this regulation. Subject facilities cannot exceed an emissions rate of $20 \mathrm{pCi} / \mathrm{m}^{2} \mathrm{~s}$ of ${ }^{222} \mathrm{Rn}$. In 1993 and 1994, LANL conducted a study to characterize emissions from the MDA G disposal site. ${ }^{15}$ This study showed an average emission rate of $0.14 \mathrm{pCi} / \mathrm{m}^{2} \mathrm{~s}$ for MDA G. The performance assessment for MDA G has determined that there will not be a significant increase in ${ }^{222} \mathrm{Rn}$ emissions in the future. ${ }^{16}$

- Potential to exceed 0.1 mrem from LANL sources of ${ }^{222} \mathrm{Rn}$ or ${ }^{220} \mathrm{Rn}$ emissions: not applicable at LANL

- Status of compliance with EPA effluent monitoring requirements as of June 3, 1996: LANL is in compliance with these requirements. 
2006 LANL Radionuclde Air Emissions Report

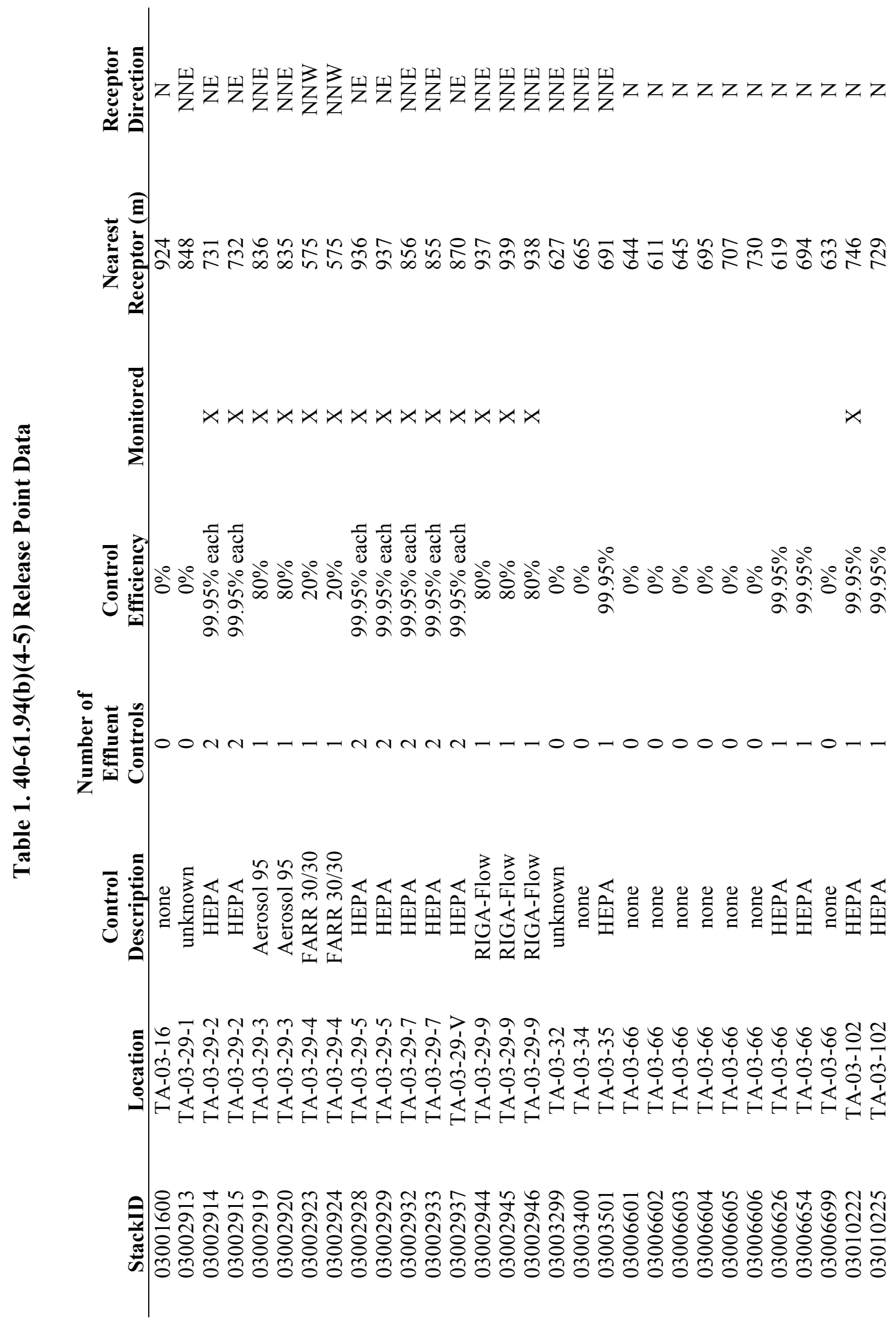




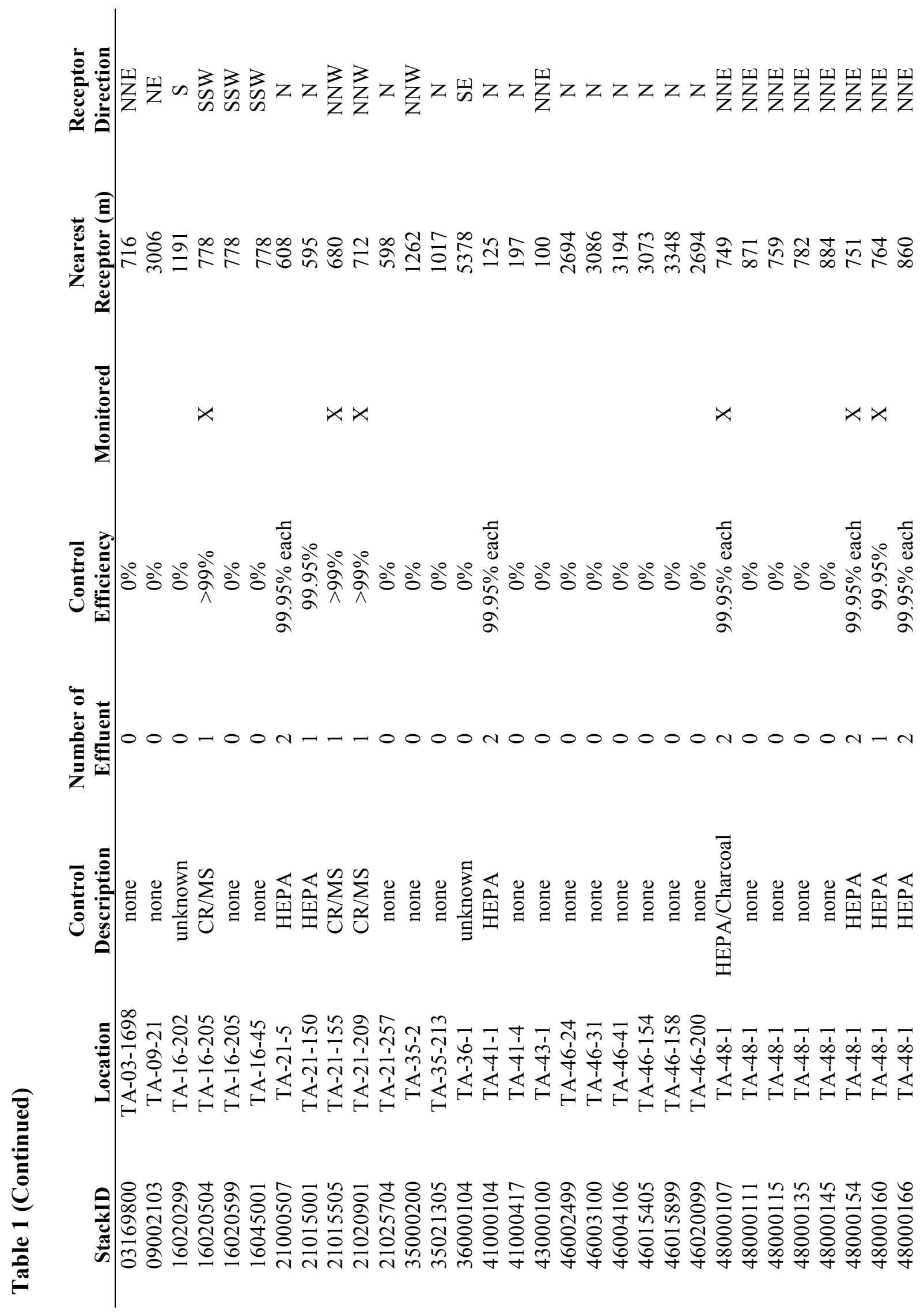




\section{LANL Radionuclide Air Emissions Report}

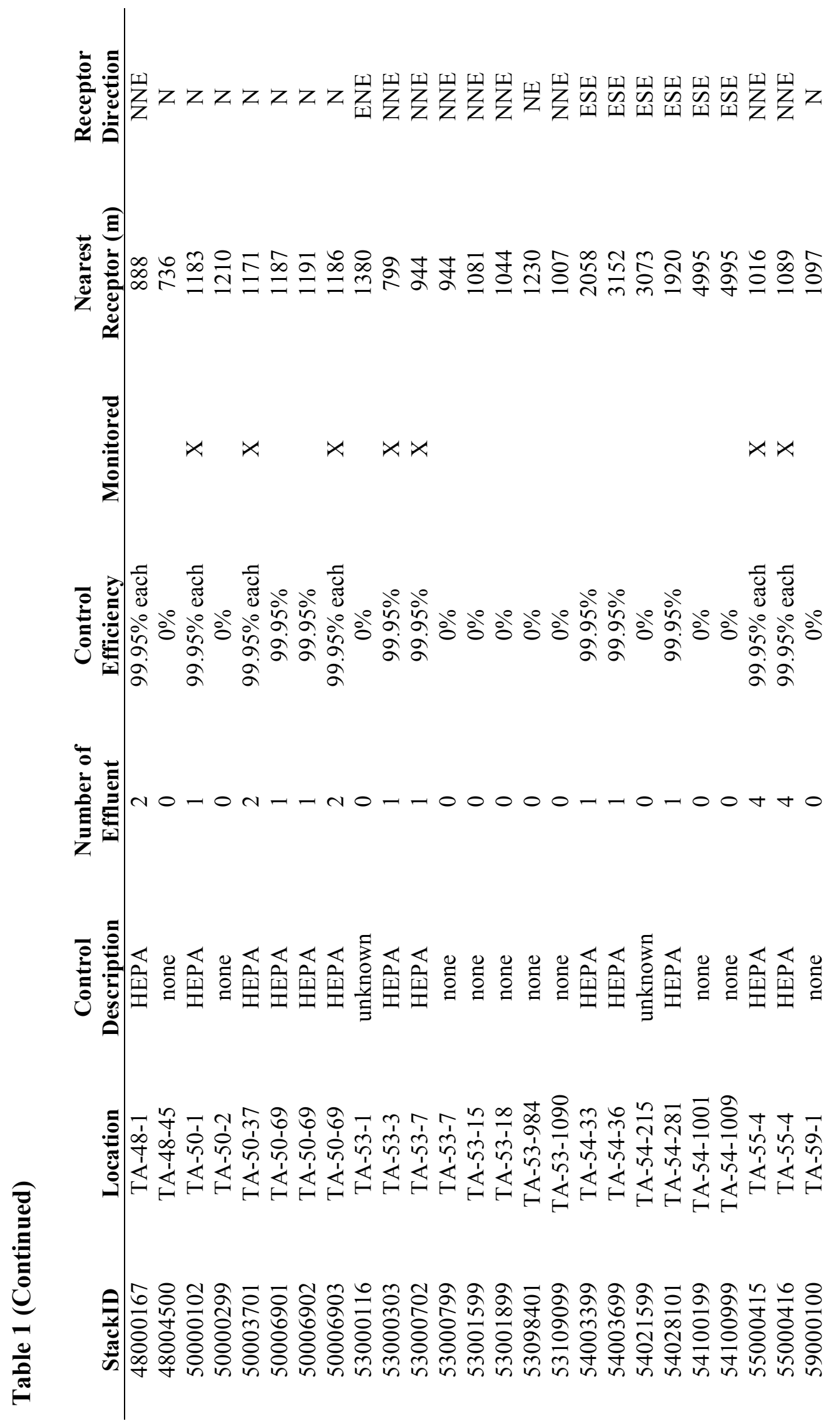


Table 2. 40-61.94(b)(7) User Supplied Data-Radionuclide Emissions

\begin{tabular}{|c|c|c|c|c|c|}
\hline StackID & Nuclide & Emissions (Ci) & StackID & Nuclide & Emissions (Ci) \\
\hline 03002914 & $\mathrm{Pu}-238$ & $3.23 \mathrm{E}-08$ & 03002946 & $Y-90(p)$ & $2.91 \mathrm{E}-08$ \\
\hline 03002915 & None & & 03010222 & $\mathrm{Pu}-239$ & $3.01 \mathrm{E}-10$ \\
\hline 03002919 & Am-241 & $6.02 \mathrm{E}-08$ & 03010222 & U-234 & $1.76 \mathrm{E}-09$ \\
\hline 03002919 & $\mathrm{Pu}-238$ & $5.06 \mathrm{E}-08$ & 16020504 & H-3 (Gas) & $3.82 \mathrm{E}+01$ \\
\hline 03002919 & Pu-239 & 2.09E-07 & 16020504 & H-3 (HTO) & $3.02 \mathrm{E}+02$ \\
\hline 03002919 & U-234 & $7.60 \mathrm{E}-08$ & 21015505 & H-3 (Gas) & 7.89E-01 \\
\hline 03002920 & $\mathrm{Pu}-239$ & $1.03 \mathrm{E}-08$ & 21015505 & H-3 (HTO) & $5.60 \mathrm{E}+01$ \\
\hline 03002920 & Th-232 & 3.33E-08 & 21020901 & H-3 (Gas) & $8.87 \mathrm{E}+00$ \\
\hline 03002923 & $\mathrm{Pu}-238$ & $2.67 \mathrm{E}-08$ & 21020901 & H-3 (HTO) & $4.39 \mathrm{E}+02$ \\
\hline 03002923 & $\mathrm{Pu}-239$ & $1.37 \mathrm{E}-08$ & 48000107 & As-73 & $7.86 \mathrm{E}-07$ \\
\hline 03002923 & Th-228 & $1.44 \mathrm{E}-07$ & 48000107 & $\mathrm{Br}-76$ & 4.79E-04 \\
\hline 03002923 & U-234 & $3.56 \mathrm{E}-06$ & 48000107 & $\mathrm{Br}-77$ & $1.44 \mathrm{E}-04$ \\
\hline 03002923 & U-235 & $1.56 \mathrm{E}-07$ & 48000107 & $\mathrm{Br}-82$ & 4.43E-06 \\
\hline 03002923 & U-238 & $3.73 \mathrm{E}-07$ & 48000107 & Ge-68 & $3.75 \mathrm{E}-03$ \\
\hline 03002923 & $\mathrm{~Pa}-234 \mathrm{~m}(\mathrm{p})$ & $3.73 \mathrm{E}-07$ & 48000107 & Ga-68 (p) & $3.75 \mathrm{E}-03$ \\
\hline 03002923 & Th-234 (p) & $3.73 \mathrm{E}-07$ & 48000107 & $\mathrm{Kr}-79$ & $2.30 \mathrm{E}+00$ \\
\hline 03002924 & Am-241 & $8.35 \mathrm{E}-08$ & 48000107 & Se-75 & $1.20 \mathrm{E}-05$ \\
\hline 03002924 & $\mathrm{Pu}-238$ & $4.64 \mathrm{E}-07$ & 48000154 & None & \\
\hline 03002924 & $\mathrm{Pu}-239$ & $1.27 \mathrm{E}-07$ & 48000160 & Ge-68 & $7.70 \mathrm{E}-06$ \\
\hline 03002924 & Th-228 & $3.84 \mathrm{E}-07$ & 48000160 & Ga-68 (p) & $7.70 \mathrm{E}-06$ \\
\hline 03002924 & U-234 & $1.24 \mathrm{E}-05$ & 48000160 & $\mathrm{~V}-48$ & $1.17 \mathrm{E}-08$ \\
\hline 03002924 & U-235 & $1.48 \mathrm{E}-07$ & 50000102 & None & \\
\hline 03002924 & U-238 & $1.03 \mathrm{E}-07$ & 50003701 & None & \\
\hline 03002924 & $\mathrm{~Pa}-234 \mathrm{~m}(\mathrm{p})$ & $1.03 \mathrm{E}-07$ & 50006903 & Am-241 & $2.61 \mathrm{E}-10$ \\
\hline 03002924 & Th-234 (p) & $1.03 \mathrm{E}-07$ & 50006903 & $\mathrm{Pu}-238$ & $8.93 \mathrm{E}-11$ \\
\hline 03002928 & $\mathrm{Pu}-238$ & $2.31 \mathrm{E}-07$ & 50006903 & $\mathrm{Pu}-239$ & $2.28 \mathrm{E}-09$ \\
\hline 03002928 & $\mathrm{Pu}-239$ & $4.54 \mathrm{E}-08$ & 53000303 & $\mathrm{C}-11$ & $8.02 \mathrm{E}+00$ \\
\hline 03002928 & U-238 & $2.88 \mathrm{E}-08$ & 53000303 & H-3 (HTO) & $2.74 \mathrm{E}+00$ \\
\hline 03002928 & $\mathrm{~Pa}-234 \mathrm{~m}(\mathrm{p})$ & $2.88 \mathrm{E}-08$ & 53000702 & Ar-41 & $1.42 \mathrm{E}+01$ \\
\hline 03002928 & Th-234 (p) & $2.88 \mathrm{E}-08$ & 53000702 & C-10 & $1.72 \mathrm{E}-01$ \\
\hline 03002929 & $\mathrm{U}-238$ & $4.57 \mathrm{E}-08$ & 53000702 & C-11 & $1.84 \mathrm{E}+02$ \\
\hline 03002929 & $\mathrm{~Pa}-234 \mathrm{~m}(\mathrm{p})$ & 4.57E-08 & 53000702 & $\mathrm{~N}-13$ & $1.37 \mathrm{E}+01$ \\
\hline 03002929 & Th-234 (p) & 4.57E-08 & 53000702 & $\mathrm{O}-14$ & $3.53 \mathrm{E}-01$ \\
\hline 03002932 & None & & 53000702 & O-15 & $2.01 \mathrm{E}+01$ \\
\hline 03002933 & Th-232 & $1.93 \mathrm{E}-08$ & 53000702 & H-3 (HTO) & $5.93 \mathrm{E}+00$ \\
\hline 03002933 & $\mathrm{U}-234$ & $6.68 \mathrm{E}-08$ & 53000702 & As-73 & $4.07 \mathrm{E}-05$ \\
\hline 03002933 & $\mathrm{U}-238$ & $2.62 \mathrm{E}-08$ & 53000702 & $\mathrm{Be}-7$ & $9.19 \mathrm{E}-07$ \\
\hline 03002933 & $\mathrm{~Pa}-234 \mathrm{~m}(\mathrm{p})$ & $2.62 \mathrm{E}-08$ & 53000702 & $\mathrm{Br}-76$ & $2.32 \mathrm{E}-03$ \\
\hline 03002933 & Th-234 (p) & $2.62 \mathrm{E}-08$ & 53000702 & $\mathrm{Br}-77$ & 2.99E-04 \\
\hline 03002937 & Th-230 & $5.83 \mathrm{E}-10$ & 53000702 & $\mathrm{Br}-82$ & $2.81 \mathrm{E}-03$ \\
\hline 03002944 & As-73 & $4.31 \mathrm{E}-05$ & 53000702 & $\mathrm{Hg}-197 \mathrm{~m}$ & $4.36 \mathrm{E}-03$ \\
\hline 03002944 & Th-232 & $2.15 \mathrm{E}-08$ & 53000702 & $\operatorname{Hg}-197(p)$ & $4.36 \mathrm{E}-03$ \\
\hline 03002945 & Th-232 & 2.03E-08 & 53000702 & $\mathrm{Na}-24$ & $1.14 \mathrm{E}-06$ \\
\hline 03002946 & $\mathrm{Br}-77$ & $8.46 \mathrm{E}-05$ & & & \\
\hline 03002946 & Se-75 & $3.45 \mathrm{E}-06$ & & & \\
\hline 03002946 & Sr-90 & $2.91 \mathrm{E}-08$ & Sour & erm table conti & d next page \\
\hline
\end{tabular}


Table 2 (Continued)

\begin{tabular}{|c|c|c|c|c|c|}
\hline StackID & Nuclide & $\begin{array}{c}\text { Emissions } \\
\text { (Ci) }\end{array}$ & StackID & Nuclide & $\begin{array}{c}\text { Emissions } \\
\text { (Ci) }\end{array}$ \\
\hline 53000702 & Os-191 & $5.29 \mathrm{E}-05$ & 55000415 & Pa-234m (p) & $8.20 \mathrm{E}-09$ \\
\hline 53000702 & Se-75 & $2.49 \mathrm{E}-05$ & 55000415 & Th-234 (p) & $8.20 \mathrm{E}-09$ \\
\hline 55000415 & Sr-90 & 8.88E-09 & 55000416 & U-238 & $1.03 \mathrm{E}-08$ \\
\hline 55000415 & Y-90 (p) & 8.88E-09 & 55000416 & $\mathrm{~Pa}-234 \mathrm{~m}(\mathrm{p})$ & $1.03 \mathrm{E}-08$ \\
\hline 55000415 & Th-230 & $3.53 \mathrm{E}-09$ & 55000416 & Th-234 (p) & $1.03 \mathrm{E}-08$ \\
\hline 55000415 & Th-232 & $5.80 \mathrm{E}-09$ & 55000416 & H-3 (Gas) & $3.74 \mathrm{E}+01$ \\
\hline 55000415 & U-235 & $7.55 \mathrm{E}-09$ & 55000416 & H-3 (HTO) & $2.80 \mathrm{E}+00$ \\
\hline 55000415 & U-238 & $8.20 \mathrm{E}-09$ & & & \\
\hline
\end{tabular}

Notes: Stacks at the CMR facility identified as 03002915 through 03002933 are recorded in the RADAIR database as N3002915 through N3002933 to indicate measurements made with the New sampling systems, effective 2001.

Starting in 2006, particulate emissions from TA-55 stacks 55000415 and 55000416 are measured from new sample systems, which consist of four independent sample systems on each stack. The four samplers are identified as 5500415A, -B, -C, and -D; and 5500416A, -B, -C, and -D. Stack emissions data reported in this table represent average emission values measured from these four samplers. In the RADAIR database, these average emissions are given the stack ID 5500415X and 5500416X, with the "X" indicating the calculated average value from the four samples. The emissions of tritium (H-3, both HT and HTO forms) from the ES-16 stack use a different sample system, and references remain unchanged in the database.

Nuclides identified with a "(p)" after the name indicate a short-lived progeny nuclide. These nuclides are included here for completeness, but do not need to be entered into CAP88-PC version 3 analyses. This new version of CAP88 will include all progeny nuclides when performing the dispersion model and dose assessment.

The term "None" in the Nuclide column indicates no detectable emissions from this source in 2006. 
Table 3. 40-61.94(b)(7) User-Supplied Data-Monitored Stack Parameters

\begin{tabular}{|c|c|c|c|c|}
\hline StackID & Height (m) & Diameter (m) & Exit Velocity $(\mathrm{m} / \mathrm{s})$ & $\begin{array}{l}\text { Nearest } \\
\text { eteorological } \\
\text { Tower }\end{array}$ \\
\hline 03002914 & 15.9 & 1.07 & 8.08 & TA-6 \\
\hline 03002915 & 15.9 & 1.05 & 23.10 & TA-6 \\
\hline 03002919 & 15.9 & 1.07 & 23.71 & TA-6 \\
\hline 03002920 & 15.9 & 1.07 & 6.98 & TA-6 \\
\hline 03002923 & 15.9 & 1.07 & 23.37 & TA-6 \\
\hline 03002924 & 15.9 & 1.06 & 15.12 & TA-6 \\
\hline 03002928 & 15.9 & 1.05 & 21.15 & TA-6 \\
\hline 03002929 & 15.9 & 1.07 & 24.26 & TA-6 \\
\hline 03002932 & 15.9 & 1.07 & 15.58 & TA-6 \\
\hline 03002933 & 15.9 & 1.06 & 26.17 & TA-6 \\
\hline 03002937 & 16.8 & 0.20 & 14.71 & TA-6 \\
\hline 03002944 & 16.5 & 1.52 & 9.15 & TA-6 \\
\hline 03002945 & 16.5 & 1.52 & 5.94 & TA-6 \\
\hline 03002946 & 16.5 & 1.88 & 8.02 & TA-6 \\
\hline 03010222 & 13.4 & 0.91 & 0.46 & TA-6 \\
\hline 16020504 & 18.3 & 0.46 & 21.38 & TA-6 \\
\hline 21015505 & 29.9 & 0.79 & 9.79 & TA-53 \\
\hline 21020901 & 22.9 & 1.22 & 10.99 & TA-53 \\
\hline 48000107 & 13.4 & 0.30 & 20.75 & TA-6 \\
\hline 48000154 & 13.1 & 0.91 & 5.53 & TA-6 \\
\hline 48000160 & 12.4 & 0.38 & 7.45 & TA-6 \\
\hline 50000102 & 15.5 & 1.82 & 11.08 & TA-6 \\
\hline 50003701 & 12.4 & 0.91 & 5.76 & TA-6 \\
\hline 50006903 & 10.5 & 0.31 & 4.94 & TA-6 \\
\hline 53000303 & 33.5 & 0.91 & 11.35 & TA-53 \\
\hline 53000702 & 13.1 & 0.91 & 8.86 & TA-53 \\
\hline 55000415 & 9.5 & 0.93 & 7.68 & TA-6 \\
\hline 55000416 & 9.5 & 0.94 & 10.74 & TA-6 \\
\hline
\end{tabular}


Table 4. 61.94(b)(7) User-Supplied Data-Monitored Stack ParametersNM State Plane Coordinates (NAD '83)

This page has been removed for operational security reasons. Please contact the Ecology and Air Quality Group at (505) 665-8855 for a hard copy of the NM State Plane coordinates for monitored stacks. 
Table 5. 40-61.94(b)(7) User-Supplied Data-Highest Off-Site Dose Location for Monitored Release Points

\begin{tabular}{|c|c|c|c|}
\hline StackID & $\begin{array}{c}\text { Associated Meteorological } \\
\text { Tower }\end{array}$ & $\begin{array}{l}\text { Distance to LANL } \\
\text { Highest Dose Location (m) }\end{array}$ & $\begin{array}{l}\text { Direction to LANL } \\
\text { Highest Dose Location }\end{array}$ \\
\hline 03002914 & TA-06 & 4,313 & ENE \\
\hline 03002915 & TA-06 & 4,314 & ENE \\
\hline 03002919 & TA-06 & 4,326 & ENE \\
\hline 03002920 & TA-06 & 4,325 & ENE \\
\hline 03002923 & TA-06 & 4,462 & ENE \\
\hline 03002924 & TA-06 & 4,464 & ENE \\
\hline 03002928 & TA-06 & 4,474 & ENE \\
\hline 03002929 & TA-06 & 4,475 & ENE \\
\hline 03002932 & TA-06 & 4,329 & ENE \\
\hline 03002933 & TA-06 & 4,327 & ENE \\
\hline 03002937 & TA-06 & 4,406 & ENE \\
\hline 03002944 & TA-06 & 4,423 & ENE \\
\hline 03002945 & TA-06 & 4,426 & ENE \\
\hline 03002946 & TA-06 & 4,425 & ENE \\
\hline 03010222 & TA-06 & 4,613 & ENE \\
\hline 16020504 & TA-06 & 8,549 & ENE \\
\hline 21015505 & TA-53 & 681 & NNW \\
\hline 21020901 & TA-53 & 713 & NNW \\
\hline 48000107 & TA-06 & 3,306 & ENE \\
\hline 48000154 & TA-06 & 3,271 & ENE \\
\hline 48000160 & TA-06 & 3,307 & ENE \\
\hline 50000102 & TA-06 & 2,998 & NE \\
\hline 50003701 & TA-06 & 3,078 & NE \\
\hline 50006903 & TA-06 & 3,126 & $\mathrm{NE}$ \\
\hline 53000303 & TA-53 & 2,143 & NW \\
\hline 53000702 & TA-53 & 2,230 & NW \\
\hline 55000415 & TA-06 & 3,150 & NE \\
\hline 55000416 & TA-06 & 3,233 & $\mathrm{NE}$ \\
\hline
\end{tabular}


Table 6. 40-61.94(b)(7) User-Supplied Data-Other Input Parameters Description

Value Units CAP88 Variable Name

Annual rainfall rate

Lid height

Annual median temp

E-vertical temperature gradient

F-vertical temperature gradient

G-vertical temperature gradient

Food supply fraction - local vegetables

Food supply fraction - vegetable regional

Food supply fraction - meat local

Food supply fraction - meat regional

Food supply fraction - meat imported

Food supply fraction - milk local

Food supply fraction - milk regional

Food supply fraction - milk imported

Ground surface roughness factor

Food supply fraction - vegetable imported

$\begin{array}{rcc}45.3 & \mathrm{~cm} / \mathrm{y} & \mathrm{RR} \\ 1600 & \mathrm{~m} & \mathrm{LIPO} \\ 281.9 & \mathrm{~K} & \mathrm{TA} \\ 0.02 & \mathrm{~K} / \mathrm{m} & \mathrm{TG} \\ 0.035 & \mathrm{~K} / \mathrm{m} & \mathrm{TG} \\ 0.035 & \mathrm{~K} / \mathrm{m} & \mathrm{TG} \\ 1 & \mathrm{~F} 1 \mathrm{~V} & \\ 0 & \mathrm{~F} 2 \mathrm{~V} & \\ 1 & \mathrm{~F} 1 \mathrm{~B} & \\ 0 & \mathrm{~F} 2 \mathrm{~B} & \\ 0 & \mathrm{~F} 3 \mathrm{~B} & \\ 1 & \mathrm{~F} 1 \mathrm{M} & \\ 0 & \mathrm{~F} 2 \mathrm{M} & \\ 0 & \mathrm{~F} 3 \mathrm{M} & \\ 0.5 & \mathrm{GSCFAC} & \\ 0 & \mathrm{~F} 3 \mathrm{~V} & \end{array}$




\section{Table 7. 40-61.94(b)(7) User-Supplied Data-Wind Frequency Arrays}

CAP88 Input Data for 2006 TA-6 Meteorological Tower

(99.0\% Data Completeness)

$\mathrm{N} A 0.000580 .000170 .000000 .000000 .000000 .00000$

NNE A 0.001270 .000370 .000000 .000000 .000000 .00000

$\mathrm{NE}$ A 0.001530 .000580 .000000 .000000 .000000 .00000

ENE A 0.003030 .001180 .000000 .000000 .000000 .00000

E A 0.003860 .002190 .000030 .000000 .000000 .00000

ESE A 0.003540 .002220 .000000 .000000 .000000 .00000

SE A 0.002330 .001870 .000000 .000000 .000000 .00000

SSE A 0.001840 .001670 .000000 .000000 .000000 .00000

S A 0.001040 .000780 .000000 .000000 .000000 .00000

SSW A 0.000550 .000400 .000000 .000000 .000000 .00000

SW A 0.000460 .000260 .000000 .000000 .000000 .00000

WSW A 0.000200 .000090 .000000 .000000 .000000 .00000

WA 0.000230 .000140 .000000 .000000 .000000 .00000

WNW A 0.000290 .000090 .000030 .000000 .000000 .00000

NW A 0.000120 .000120 .000000 .000000 .000000 .00000

NNW A 0.000200 .000260 .000000 .000000 .000000 .00000

N B 0.000200 .000090 .000000 .000000 .000000 .00000

NNE B 0.000320 .000170 .000000 .000000 .000000 .00000

NE B 0.000520 .000750 .000000 .000000 .000000 .00000

ENE B 0.001240 .001210 .000000 .000000 .000000 .00000

E B 0.001670 .002420 .000000 .000000 .000000 .00000

ESE B 0.001300 .002850 .000000 .000000 .000000 .00000

SE B 0.000890 .002560 .000000 .000000 .000000 .00000

SSE B 0.000750 .002050 .000000 .000000 .000000 .00000

S B 0.000460 .000890 .000000 .000000 .000000 .00000

SSW B 0.000170 .000290 .000030 .000000 .000000 .00000

SW B 0.000060 .000260 .000000 .000000 .000000 .00000

WSW B 0.000120 .000170 .000000 .000000 .000000 .00000

W B 0.000120 .000060 .000000 .000000 .000000 .00000

WNW B 0.000140 .000090 .000090 .000000 .000000 .00000

NW B 0.000030 .000230 .000060 .000000 .000000 .00000

NNW B 0.000090 .000140 .000030 .000000 .000000 .00000

$\mathrm{N} \mathrm{C} 0.000200 .000490 .000090 .000000 .000000 .00000$

NNE C 0.000550 .000920 .000030 .000000 .000000 .00000

NE C 0.001090 .002310 .000120 .000000 .000000 .00000

ENE C 0.001820 .004260 .000060 .000000 .000000 .00000

E C 0.002450 .005470 .000090 .000000 .000000 .00000

ESE C 0.001410 .005880 .000090 .000000 .000000 .00000

SE C 0.001350 .006430 .000030 .000000 .000000 .00000

SSE C 0.000840 .007950 .000290 .000000 .000000 .00000

S C 0.000780 .004580 .000400 .000000 .000000 .00000

SSW C 0.000400 .002050 .000460 .000000 .000000 .00000

SW C 0.000140 .000810 .000260 .000000 .000000 .00000

WSW C 0.000320 .000460 .000170 .000000 .000000 .00000

W C 0.000030 .000290 .000090 .000000 .000000 .00000

WNW C 0.000120 .000580 .000290 .000000 .000000 .00000

NW C 0.000230 .000260 .000350 .000000 .000000 .00000

NNW C 0.000290 .000520 .000260 .000000 .000000 .00000 


\section{Table 7 (continued)}

N D 0.004380 .006190 .003460 .001010 .000030 .00000

NNE D 0.005700 .011210 .005940 .001090 .000030 .00000

NE D 0.004980 .010890 .003460 .000200 .000030 .00000

ENE D 0.005880 .007890 .001070 .000060 .000030 .00000

E D 0.006830 .005790 .000230 .000000 .000000 .00000

ESE D 0.005330 .007060 .000780 .000090 .000000 .00000

SE D 0.004930 .010800 .001580 .000320 .000000 .00000

SSE D 0.005010 .019420 .011210 .000520 .000000 .00000

S D 0.006310 .022680 .031780 .004780 .000000 .00000

SSW D 0.005100 .019020 .025960 .009080 .000550 .00003

SW D 0.003720 .013460 .016220 .006340 .001350 .00009

WSW D 0.003980 .010400 .012420 .007780 .002070 .00026

W D 0.002970 .008410 .013570 .011410 .003050 .00017

WNW D 0.003720 .008640 .013250 .012880 .006740 .00187

NW D 0.003430 .009340 .013570 .008210 .000860 .00032

NNW D 0.004410 .006890 .005500 .001440 .000000 .00000

N E 0.001120 .003520 .001580 .000000 .000000 .00000

NNE E 0.001210 .003950 .002540 .000000 .000000 .00000

$\mathrm{NE}$ E 0.001240 .001990 .000400 .000000 .000000 .00000

ENE E 0.001040 .000810 .000060 .000000 .000000 .00000

E E 0.000840 .000400 .000000 .000000 .000000 .00000

ESE E 0.000750 .000690 .000000 .000000 .000000 .00000

SE E 0.000860 .000920 .000060 .000000 .000000 .00000

SSE E 0.001210 .002850 .000120 .000000 .000000 .00000

S E 0.001670 .008560 .002160 .000000 .000000 .00000

SSW E 0.001380 .014180 .005730 .000000 .000000 .00000

SW E 0.001670 .011270 .008330 .000000 .000000 .00000

WSW E 0.001210 .004350 .005160 .000000 .000000 .00000

W E 0.000920 .002540 .002160 .000000 .000000 .00000

WNW E 0.001210 .003860 .005070 .000000 .000000 .00000

NW E 0.001270 .005790 .007170 .000000 .000000 .00000

NNW E 0.001300 .004980 .001560 .000000 .000000 .00000

N F 0.006370 .009220 .000720 .000000 .000000 .00000

NNE F 0.005270 .003460 .000120 .000000 .000000 .00000

NE F 0.003370 .001300 .000000 .000000 .000000 .00000

ENE F 0.002050 .000120 .000000 .000000 .000000 .00000

E F 0.001560 .000030 .000000 .000000 .000000 .00000

ESE F 0.001040 .000060 .000000 .000000 .000000 .00000

SE F 0.001700 .000200 .000000 .000000 .000000 .00000

SSE F 0.002220 .000550 .000030 .000000 .000000 .00000

S F 0.003920 .002790 .000090 .000000 .000000 .00000

SSW F 0.005270 .005470 .000400 .000000 .000000 .00000

SW F 0.008640 .017030 .001840 .000000 .000000 .00000

WSW F 0.009100 .027950 .004180 .000000 .000000 .00000

W F 0.008820 .024580 .003490 .000000 .000000 .00000

WNW F 0.008100 .022850 .002970 .000000 .000000 .00000

NW F 0.008870 .025530 .002310 .000000 .000000 .00000

NNW F 0.008850 .013400 .000780 .000000 .000000 .00000 


\section{Table 7 (continued)}

CAP88 Input Data for 2006 TA-53 Meteorological Tower (99.0\% Data Completeness)

NA 0.000930 .000380 .000000 .000000 .000000 .00000

NNE A 0.003010 .000690 .000030 .000000 .000000 .00000

$\mathrm{NE}$ A 0.004660 .002000 .000000 .000000 .000000 .00000

ENE A 0.006360 .003530 .000000 .000000 .000000 .00000

EA 0.004690 .004110 .000000 .000000 .000000 .00000

ESE A 0.002920 .003240 .000000 .000000 .000000 .00000

SE A 0.002630 .002370 .000000 .000000 .000000 .00000

SSE A 0.002230 .002020 .000030 .000000 .000000 .00000

S A 0.001210 .001560 .000000 .000000 .000000 .00000

SSW A 0.000840 .000840 .000030 .000000 .000000 .00000

SW A 0.000750 .000690 .000000 .000000 .000000 .00000

WSW A 0.000580 .000120 .000000 .000000 .000000 .00000

WA 0.000400 .000290 .000000 .000000 .000000 .00000

WNW A 0.000460 .000290 .000000 .000000 .000000 .00000

NW A 0.000490 .000260 .000000 .000000 .000000 .00000

NNW A 0.000810 .000200 .000000 .000030 .000000 .00000

N B 0.000170 .000200 .000030 .000000 .000000 .00000

NNE B 0.000400 .000640 .000060 .000000 .000000 .00000

$\mathrm{NE}$ B 0.000780 .001970 .000000 .000000 .000000 .00000

ENE B 0.001740 .003470 .000120 .000000 .000000 .00000

E B 0.000900 .003300 .000030 .000000 .000000 .00000

ESE B 0.000750 .002750 .000000 .000000 .000000 .00000

SE B 0.000670 .002050 .000000 .000000 .000000 .00000

SSE B 0.000670 .002080 .000000 .000000 .000000 .00000

S B 0.000550 .001710 .000030 .000000 .000000 .00000

SSW B 0.000170 .001010 .000000 .000000 .000000 .00000

SW B 0.000060 .000350 .000000 .000000 .000000 .00000

WSW B 0.000060 .000230 .000000 .000000 .000000 .00000

W B 0.000030 .000230 .000060 .000000 .000000 .00000

WNW B 0.000030 .000490 .000060 .000000 .000000 .00000

NW B 0.000090 .000230 .000030 .000000 .000000 .00000

NNW B 0.000140 .000380 .000030 .000000 .000000 .00000

$\mathrm{N} \mathrm{C} 0.000260 .000520 .000520 .000000 .000000 .00000$

NNE C 0.001190 .001680 .000430 .000000 .000000 .00000

$\mathrm{NE} C 0.001560 .004770 .000320 .000000 .000000 .00000$

ENE C 0.001910 .008010 .000170 .000000 .000000 .00000

E C 0.000950 .006710 .000170 .000000 .000000 .00000

ESE C 0.000930 .005290 .000060 .000000 .000000 .00000

SE C 0.000780 .004310 .000060 .000000 .000000 .00000

SSE C 0.000580 .006070 .000170 .000000 .000000 .00000

S C 0.000550 .004370 .000810 .000000 .000000 .00000

SSW C 0.000230 .001650 .000380 .000000 .000000 .00000

SW C 0.000140 .001210 .000400 .000030 .000000 .00000

WSW C 0.000090 .001100 .000810 .000000 .000000 .00000

W C 0.000090 .001160 .001710 .000120 .000000 .00000

WNW C 0.000200 .000900 .001070 .000060 .000000 .00000

NW C 0.000140 .000640 .000580 .000000 .000000 .00000

NNW C 0.000120 .000230 .000350 .000000 .000000 .00000 


\section{Table 7 (continued)}

N D 0.006860 .009000 .010410 .003010 .000290 .00000

NNE D 0.006590 .012350 .009520 .001620 .000060 .00000

NE D 0.006390 .010470 .003640 .000380 .000000 .00000

ENE D 0.004570 .009200 .001500 .000200 .000000 .00000

E D 0.004170 .006680 .001160 .000060 .000000 .00000

ESE D 0.003240 .004630 .000900 .000350 .000000 .00000

SE D 0.002600 .005670 .001500 .000320 .000090 .00000

SSE D 0.002750 .010760 .011890 .003090 .000320 .00000

S D 0.003270 .018250 .031990 .013190 .000930 .00000

SSW D 0.001940 .016630 .032920 .020020 .002780 .00017

SW D 0.001940 .012900 .022180 .007750 .001790 .00026

WSW D 0.002050 .007660 .012260 .008270 .002230 .00040

W D 0.002340 .009260 .015450 .007030 .001500 .00038

WNW D 0.002690 .006830 .010850 .006250 .001680 .00043

NW D 0.004450 .004310 .004970 .004220 .000350 .00000

NNW D 0.005210 .006050 .005120 .002230 .000320 .00000

$\mathrm{N} E 0.004450 .009000 .002600 .000000 .000000 .00000$

NNE E 0.003620 .007430 .002140 .000000 .000000 .00000

$\mathrm{NE}$ E 0.001940 .003760 .001040 .000000 .000000 .00000

ENE E 0.001210 .002200 .000380 .000000 .000000 .00000

E E 0.000980 .001790 .000140 .000000 .000000 .00000

ESE E 0.001330 .001480 .000120 .000000 .000000 .00000

SE E 0.000750 .001190 .000120 .000000 .000000 .00000

SSE E 0.000930 .002260 .000380 .000000 .000000 .00000

S E 0.000750 .007550 .004400 .000000 .000000 .00000

SSW E 0.001270 .016890 .025830 .000000 .000000 .00000

SW E 0.001530 .023110 .014230 .000000 .000000 .00000

WSW E 0.001740 .011950 .012470 .000000 .000000 .00000

W E 0.001210 .010350 .010090 .000000 .000000 .00000

WNW E 0.001940 .008390 .004250 .000000 .000000 .00000

NW E 0.002690 .004710 .002810 .000000 .000000 .00000

NNW E 0.003760 .006860 .003330 .000000 .000000 .00000

N F 0.006280 .002490 .000030 .000000 .000000 .00000

NNE F 0.007090 .002260 .000120 .000000 .000000 .00000

NE F 0.005810 .001760 .000000 .000000 .000000 .00000

ENE F 0.004310 .001390 .000000 .000000 .000000 .00000

E F 0.003470 .000430 .000000 .000000 .000000 .00000

ESE F 0.003150 .000520 .000000 .000000 .000000 .00000

SE F 0.003410 .001300 .000000 .000000 .000000 .00000

SSE F 0.003240 .001940 .000000 .000000 .000000 .00000

S F 0.005670 .004220 .000000 .000000 .000000 .00000

SSW F 0.005060 .007140 .000690 .000000 .000000 .00000

SW F 0.004890 .004190 .000120 .000000 .000000 .00000

WSW F 0.004690 .007900 .001500 .000000 .000000 .00000

W F 0.004190 .008070 .001560 .000000 .000000 .00000

WNW F 0.004020 .006650 .000120 .000000 .000000 .00000

NW F 0.004950 .003270 .000120 .000000 .000000 .00000

NNW F 0.005030 .002630 .000120 .000000 .000000 .00000 


\begin{tabular}{|c|c|c|c|c|c|c|c|c|c|c|c|c|c|c|c|}
\hline $\begin{array}{l}0 \\
0 \\
0 \\
f\end{array}$ & $\stackrel{\infty}{\stackrel{\infty}{+}}$ & $\begin{array}{ll}1 & 0 \\
\sigma & 0 \\
\sigma & 0\end{array}$ & $\frac{n}{m}$ & $\stackrel{n}{=}$ & ڤे & तิ & $\begin{array}{l}\infty \\
\infty \\
\\
\end{array}$ & ñ & in & $\frac{d}{\sigma}$ & $\stackrel{\infty}{\infty}$ & ஓ & $\frac{n}{n}$ & $\frac{8}{6}$ & 守 \\
\hline I & $\stackrel{8}{\circ} \stackrel{0}{\circ}$ & $\frac{n}{n} n$ & $\infty$ & $\stackrel{0}{n}$ & $\hat{q}$ & 0 & $\begin{array}{l}\mathbb{0} \\
\stackrel{D}{n}\end{array}$ & $\underline{I}$ & $\vec{n}$ & $\begin{array}{l}0 \\
\frac{0}{\infty} \\
\infty\end{array}$ & ญे ڤે & f & $\hat{n}$ & 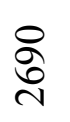 & $\stackrel{m}{\gamma}$ \\
\hline 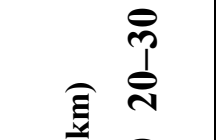 & $\hat{a} \approx$ & ते & $m$ & $\infty$ & r & 0 & ¿ & $\stackrel{\overbrace{}}{~}$ & 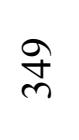 & $\stackrel{8}{=}$ & $\stackrel{\infty}{\infty}$ & ñ & $\bar{\Xi}$ & $\stackrel{\infty}{\infty}$ & $\frac{ \pm}{2}$ \\
\hline 氙 & $\stackrel{0}{\infty} \infty$ & $\infty \sim$ & 0 & $a$ & $a$ & $\nabla$ & $\nabla$ & $r$ & $\stackrel{i}{n}$ & - & $\stackrel{m}{-}$ & $\stackrel{\infty}{\cong}$ & ஜे & $\stackrel{\infty}{\stackrel{一}{\beth}}$ & $\because$ \\
\hline 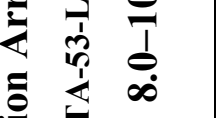 & 00 & 00 & 0 & 0 & $\sim$ & $\nabla$ & $n$ & 2 & $\frac{m}{m}$ & $\ddot{n}$ & $=$ & - & 0 & 0 & 0 \\
\hline$\stackrel{1}{1}$ & 0 & 0 in & 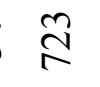 & 0 & 0 & 0 & 0 & 0 & 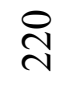 & 愳 & 0 & $\sim$ & 0 & 0 & 0 \\
\hline 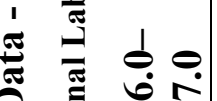 & 00 & 0 ळे & $\stackrel{m}{b}$ & 0 & 0 & 0 & 0 & 0 & లn & 莡 & 0 & 0 & 0 & 0 & 0 \\
\hline 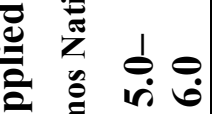 & $\circ \bar{\lambda}$ & $\bar{v} \stackrel{n}{\forall}$ & $\underset{\infty}{0}$ & 0 & 0 & 0 & 0 & 0 & 0 & 0 & 0 & 0 & 0 & 0 & 0 \\
\hline 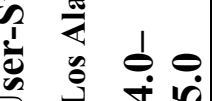 & $\stackrel{\infty}{\stackrel{\infty}{\sim}}$ & $\frac{\infty}{N} \frac{\infty}{b}$ & 守 & $\underline{6}$ & 0 & 0 & 0 & 0 & 0 & 0 & 0 & 0 & 0 & 0 & $\stackrel{d}{~}$ \\
\hline 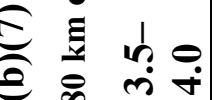 & t & $\hat{\nu} \stackrel{\infty}{\circ}$ & $\stackrel{\curvearrowright}{\infty}$ & ๑ & 0 & 0 & 0 & 0 & 0 & 0 & 0 & 0 & 0 & 0 & 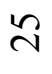 \\
\hline 管 & $\infty$ \& & $\infty \underset{\infty}{\infty}$ & $\stackrel{\circ}{\sim}$ & 0 & 0 & 0 & 0 & 0 & 0 & 0 & 0 & 0 & 0 & 0 & 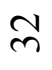 \\
\hline 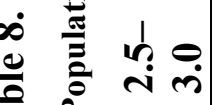 & $n$ o & 을 & $\infty$ & 0 & 0 & 0 & 0 & 0 & 0 & 0 & 0 & 0 & 0 & 0 & $\infty$ \\
\hline 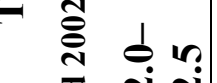 & 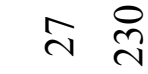 & Din & $\cong$ & 0 & 0 & 0 & 0 & 0 & 0 & 0 & 0 & 0 & 0 & 0 & $\infty$ \\
\hline 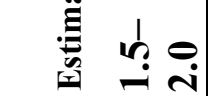 & in $\stackrel{\infty}{+}$ & $\infty \bar{\sim}$ & 음 & 0 & 0 & 0 & 0 & 0 & 0 & 0 & 0 & 0 & 0 & $\sim$ & $n$ \\
\hline بs & $=\Xi$ & $= \pm$ & 0 & 0 & 0 & 0 & 0 & 0 & 0 & 0 & 0 & 0 & 0 & & $=$ \\
\hline$\stackrel{\infty}{0}$ & $a$ & $a$ & 0 & 0 & 0 & 0 & 0 & 0 & 0 & 0 & 0 & 0 & 0 & $r$ & $r$ \\
\hline & $\frac{8}{z}$ & $\frac{3}{2}$ & $\sum_{3}^{3}$ & 3 & $\begin{array}{l}3 \\
0 \\
3\end{array}$ & 分 & $\begin{array}{l}3 \\
\infty \\
n\end{array}$ & $n$ & $\sqrt{n}$ & 药 & $\begin{array}{l}\text { 至 } \\
\text { II }\end{array}$ & 巧 & $\sum_{I I}^{1}$ & 㟐 & Z \\
\hline
\end{tabular}


Table 9. 40-61.94(b)(7) User-Supplied Data-Modeling Parameters for LANL Non-Point Sources

LANL Air Activation Sources

\begin{tabular}{|c|c|c|c|c|c|}
\hline Source & Radionuclide & $\begin{array}{c}\text { Emission } \\
\text { (Ci) }\end{array}$ & $\begin{array}{c}\text { Area of } \\
\text { Source } \\
\left(\mathbf{m}^{3}\right) \\
\end{array}$ & $\begin{array}{c}\text { Distance to } \\
\text { LANL } \\
\text { Maximum } \\
\text { Dose Location } \\
\text { (m) } \\
\end{array}$ & $\begin{array}{l}\text { Direction to } \\
\text { LANL } \\
\text { Maximum } \\
\text { Dose } \\
\text { Location } \\
\end{array}$ \\
\hline \multirow[t]{2}{*}{ TA-53 Switchyard } & ${ }^{41} \mathrm{Ar}$ & $1.51 \mathrm{E}+00$ & 484 & 2114 & NW \\
\hline & ${ }^{11} \mathrm{C}$ & $3.62 \mathrm{E}+01$ & 484 & 2114 & NW \\
\hline \multirow[t]{2}{*}{ TA-53-1L Service Area } & ${ }^{41} \mathrm{Ar}$ & $4.78 \mathrm{E}+00$ & 1.0 & 2229 & NW \\
\hline & ${ }^{11} \mathrm{C}$ & $1.14 \mathrm{E}+02$ & 1.0 & 2229 & NW \\
\hline
\end{tabular}




\section{Table 10. Environmental Data-Compliance Stations}

2006 Effective Dose Equivalent (net in mrem) measured at air sampling locations around LANL.

\begin{tabular}{|c|c|c|c|c|c|c|c|c|c|}
\hline & Site Number and Name & H-3 & $\begin{array}{c}\text { Am- } \\
241 \\
\end{array}$ & $\begin{array}{l}\text { Pu- } \\
238 \\
\end{array}$ & $\begin{array}{l}\text { Pu- } \\
239 \\
\end{array}$ & U-234 & U-235 & U-238 & $\begin{array}{c}\text { Rounded } \\
\text { Total } \\
\text { (mrem) }\end{array}$ \\
\hline 06 & 48th Street & 0.00 & 0.00 & 0.00 & 0.00 & 0.00 & 0.00 & 0.00 & 0.00 \\
\hline 08 & McDonalds & 0.02 & 0.00 & 0.00 & 0.00 & 0.01 & 0.00 & 0.00 & 0.03 \\
\hline 09 & Los Alamos Airport Terminal & 0.02 & 0.00 & 0.00 & 0.15 & 0.03 & 0.00 & 0.01 & 0.22 \\
\hline 10 & Eastgate & 0.04 & 0.00 & 0.00 & 0.00 & 0.00 & 0.00 & 0.00 & 0.05 \\
\hline 11 & Well PM-1 (East. Jemez) & 0.02 & 0.00 & 0.00 & 0.00 & 0.00 & 0.00 & 0.00 & 0.03 \\
\hline 12 & Royal Crest Trailer Court & 0.02 & 0.00 & 0.00 & 0.00 & 0.00 & 0.00 & 0.00 & 0.02 \\
\hline 13 & Rocket Park & 0.02 & 0.00 & 0.00 & 0.00 & 0.00 & 0.00 & 0.01 & 0.04 \\
\hline 14 & Pajarito Acres & 0.01 & 0.01 & 0.00 & 0.00 & 0.00 & 0.00 & 0.00 & 0.03 \\
\hline 15 & White Rock Fire Station & 0.02 & 0.00 & 0.00 & 0.00 & 0.00 & 0.00 & 0.00 & 0.02 \\
\hline 16 & White Rock Nazarene Ch. & 0.02 & 0.00 & 0.00 & 0.00 & 0.00 & 0.00 & 0.00 & 0.03 \\
\hline 20 & TA-21 Area B & 0.03 & 0.03 & 0.00 & 0.32 & 0.02 & 0.00 & 0.01 & 0.42 \\
\hline 32 & County Landfill & 0.03 & 0.01 & 0.00 & 0.00 & 0.03 & 0.00 & 0.03 & 0.10 \\
\hline 60 & LA Canyon & 0.01 & 0.00 & 0.00 & 0.00 & 0.00 & 0.00 & 0.01 & 0.03 \\
\hline 61 & LA Hospital & 0.01 & 0.00 & 0.00 & 0.00 & 0.00 & 0.00 & 0.00 & 0.02 \\
\hline 62 & Crossroads Bible Church & 0.02 & 0.00 & 0.00 & 0.00 & 0.01 & 0.00 & 0.01 & 0.05 \\
\hline 63 & Monte Rey South & 0.01 & 0.00 & 0.00 & 0.00 & 0.00 & 0.00 & 0.00 & 0.03 \\
\hline 66 & Los Alamos Inn - South & 0.02 & 0.00 & 0.00 & 0.06 & 0.01 & 0.00 & 0.01 & 0.09 \\
\hline 67 & TA-3 Research Park & 0.01 & 0.00 & 0.00 & 0.00 & 0.01 & 0.00 & 0.01 & 0.03 \\
\hline 68 & Los Alamos Airport Road & 0.03 & 0.00 & 0.00 & 0.01 & 0.00 & 0.00 & 0.00 & 0.05 \\
\hline
\end{tabular}


Table 11. Environmental Data-Compliance Stations

2006 Analytical Completeness and Air Sampler Operation Summary

Percent Analytical Completeness

\begin{tabular}{|c|c|c|c|c|c|c|c|c|c|}
\hline \multirow{2}{*}{\multicolumn{2}{|c|}{ Site Number and Name }} & & \multirow{2}{*}{$\begin{array}{l}\text { Percent } \\
\text { run } \\
\text { time }\end{array}$} \\
\hline & & H-3 & $\begin{array}{c}\text { Am- } \\
241\end{array}$ & $\begin{array}{l}\text { Pu- } \\
238\end{array}$ & $\begin{array}{l}\text { Pu- } \\
239\end{array}$ & $\mathrm{U}-234$ & $\mathrm{U}-\mathbf{2 3 5}$ & $\mathrm{U}-\mathbf{2 3 8}$ & \\
\hline 06 & 48th Street & 100 & 100 & 100 & 100 & 100 & 100 & 100 & 99.4 \\
\hline 08 & McDonalds & 100 & 100 & 100 & 100 & 100 & 100 & 100 & 99.5 \\
\hline 09 & $\begin{array}{l}\text { Los Alamos Airport } \\
\text { Terminal }\end{array}$ & 100 & 100 & 100 & 100 & 100 & 100 & 100 & 99.5 \\
\hline 10 & Eastgate & 100 & 100 & 100 & 100 & 100 & 100 & 100 & 99.6 \\
\hline 11 & Well PM-1 (East. Jemez) & 100 & 100 & 100 & 100 & 100 & 100 & 100 & 99.6 \\
\hline 12 & $\begin{array}{l}\text { Royal Crest Trailer } \\
\text { Court }\end{array}$ & 100 & 100 & 100 & 100 & 100 & 100 & 100 & 99.0 \\
\hline 13 & Rocket Park & 100 & 100 & 100 & 100 & 100 & 100 & 100 & 99.6 \\
\hline 14 & Pajarito Acres & 100 & 100 & 100 & 100 & 100 & 100 & 100 & 98.5 \\
\hline 15 & White Rock Fire Station & 100 & 100 & 100 & 100 & 100 & 100 & 100 & 99.6 \\
\hline 16 & $\begin{array}{l}\text { White Rock Nazarene } \\
\text { Ch. }\end{array}$ & 100 & 100 & 100 & 100 & 100 & 100 & 100 & 99.5 \\
\hline 20 & TA-21 Area B & 100 & 100 & 100 & 100 & 100 & 100 & 100 & 99.1 \\
\hline 32 & County Landfill & 100 & 100 & 100 & 100 & 100 & 100 & 100 & 99.6 \\
\hline 60 & LA Canyon & 100 & 100 & 100 & 100 & 100 & 100 & 100 & 99.3 \\
\hline 61 & LA Hospital & 100 & 100 & 100 & 100 & 100 & 100 & 100 & 99.5 \\
\hline 62 & Crossroads Bible Church & 100 & 100 & 100 & 100 & 100 & 100 & 100 & 99.5 \\
\hline 63 & Monte Rey South & 100 & 100 & 100 & 100 & 100 & 100 & 100 & 97.6 \\
\hline 66 & Los Alamos Inn - South & 100 & 100 & 100 & 100 & 100 & 100 & 100 & 99.5 \\
\hline 67 & TA-3 Research Park & 100 & 100 & 100 & 100 & 100 & 100 & 100 & 98.9 \\
\hline 68 & $\begin{array}{l}\text { Los Alamos Airport } \\
\text { Road }\end{array}$ & 100 & 100 & 100 & 100 & 100 & 100 & 100 & 99.5 \\
\hline
\end{tabular}


Table 12. LANSCE Monthly Assessments and Summary

\begin{tabular}{lccc}
\multicolumn{1}{c}{ Description } & StackID & $\begin{array}{c}\text { Dose at East } \\
\text { Gate } \\
\text { Receptor }\end{array}$ & $\begin{array}{c}\text { Dose at } \\
\text { Airport } \\
\text { Terminal } \\
\text { Receptor }\end{array}$ \\
\hline LANSCE-stack-Annual (GMAP only) & 53000303 & $1.18 \mathrm{E}-03$ & $1.54 \mathrm{E}-04$ \\
LANSCE-stack-PVAP* & 53000303 & $3.04 \mathrm{E}-04$ & $3.97 \mathrm{E}-05$ \\
LANSCE-Non-CAP88 Radionuclides* & 53000303 & none & none \\
LANSCE-stack-January & 53000702 & none & none \\
LANSCE-stack-February & 53000702 & none & none \\
LANSCE-stack-March & 53000702 & none & none \\
LANSCE-stack-April & 53000702 & $6.92 \mathrm{E}-04$ & $6.49 \mathrm{E}-05$ \\
LANSCE stack-May & 53000702 & $7.42 \mathrm{E}-03$ & $6.85 \mathrm{E}-04$ \\
LANSCE stack-June & 53000702 & $8.86 \mathrm{E}-02$ & $6.26 \mathrm{E}-04$ \\
LANSCE stack-July & 53000702 & $9.05 \mathrm{E}-03$ & $8.75 \mathrm{E}-04$ \\
LANSCE stack-August & 53000702 & $8.48 \mathrm{E}-03$ & $5.56 \mathrm{E}-04$ \\
LANSCE stack-September & 53000702 & $1.81 \mathrm{E}-02$ & $1.29 \mathrm{E}-03$ \\
LANSCE-stack-October & 53000702 & $7.18 \mathrm{E}-03$ & $8.31 \mathrm{E}-04$ \\
LANSCE-stack-November & 53000702 & $6.41 \mathrm{E}-03$ & $7.73 \mathrm{E}-04$ \\
LANSCE-stack-December & 53000702 & $6.09 \mathrm{E}-03$ & $1.12 \mathrm{E}-03$ \\
LANSCE-stack-PVAP* & 53000702 & $1.62 \mathrm{E}-03$ & $1.61 \mathrm{E}-04$ \\
LANSCE-Non-CAP88 Radionuclides* & 53000702 & $3.8 \mathrm{E}-06$ & $3.8 \mathrm{E}-06$ \\
LANSCE-Fugitive Emissions - & & & \\
Switchyard & & $3.06 \mathrm{E}-02$ & $1.96 \mathrm{E}-03$ \\
LANSCE-Fugitive Emissions - 1L Area & $530003 \mathrm{SY}$ & $6.72 \mathrm{E}-02$ & $5.70 \mathrm{E}-03$ \\
LANSCE Summary & & $1.73 \mathrm{E}-01$ & $1.48 \mathrm{E}-02$ \\
\hline
\end{tabular}

* Annual Value 


\section{LANL Radionuclide Air Emissions Report}

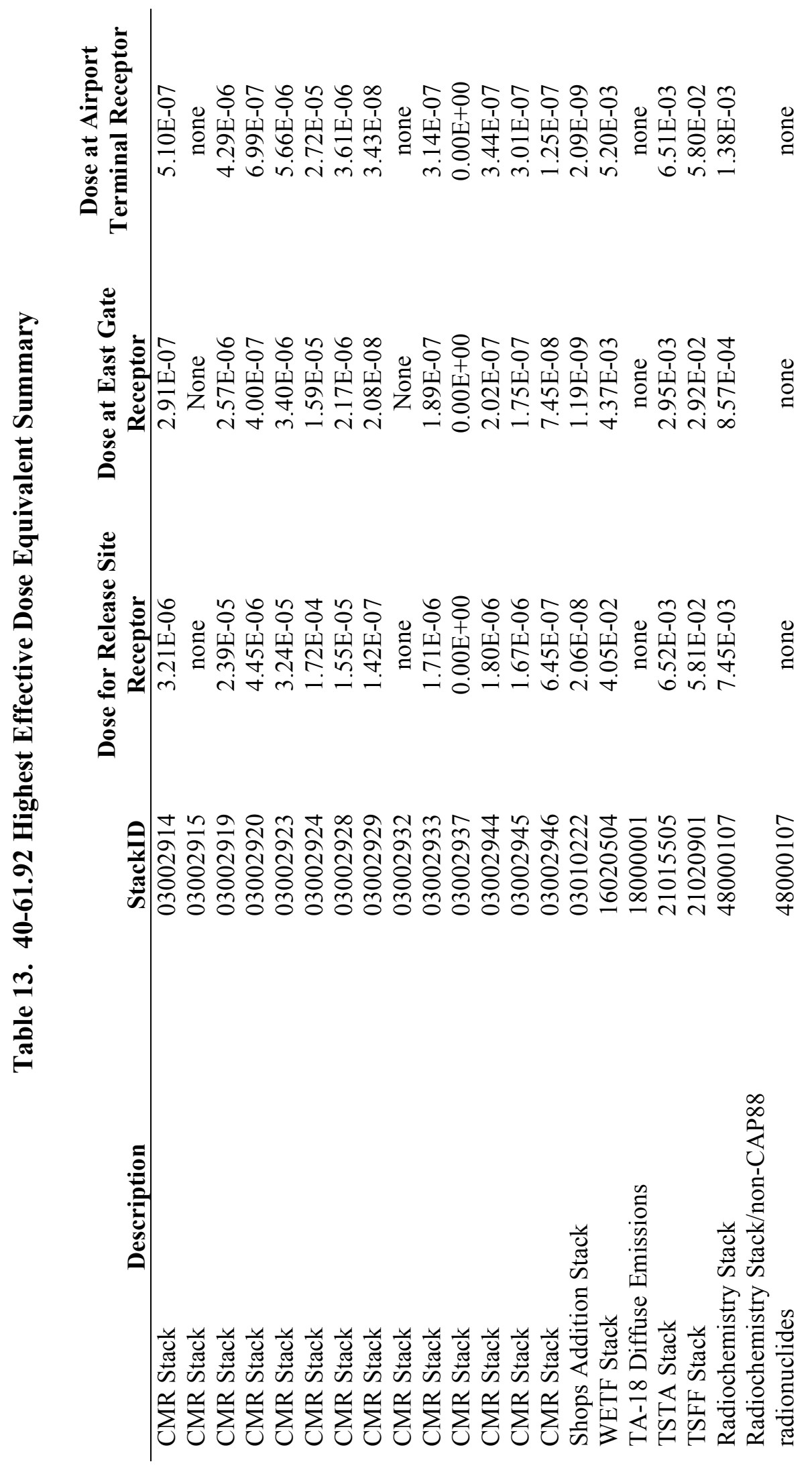




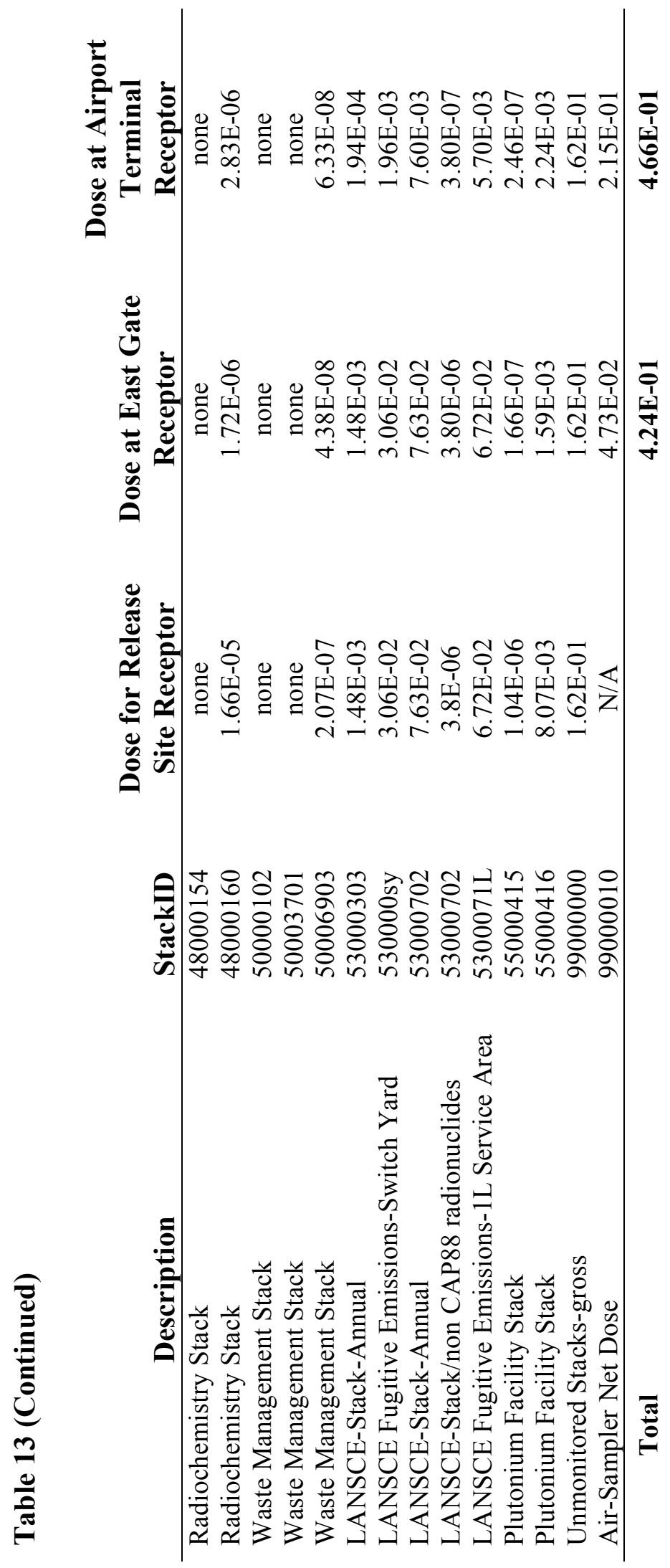




\section{LANL Radionuclide Air Emissions Report}

\subsection{4(b)(9) Certification}

I certify under penalty of law that I have personally examined and am familiar with the information submitted herein and based on my inquiry of those individuals immediately responsible for obtaining the information, I believe that the submitted information is true, accurate, and complete. I am aware that there are significant penalties for submitting false information including the possibility of fine and imprisonment. See 18 U.S.C. 1001.

Signature: signed on $6 / 14 / 07$

Date:

Daniel E. Glenn, Owner

Acting Manager

Los Alamos Site Office

National Nuclear Security Administration

U.S. Department of Energy

Signature: signed on $6 / 14 / 07$

Date:

Richard S. Watkins, Operator

Associate Director

Environment, Safety, Health and Quality Division

Los Alamos National Security, LLC

Los Alamos National Laboratory 


\section{LANL Radionuclide Air Emissions Report}

\section{References}

1. Los Alamos National Laboratory, "Shutdown of Tritium Sampling Systems at TA-21-155 and TA-21-209," ENV-EAQ:06-240, September 1, 2006.

2. Los Alamos National Laboratory, “Environmental Surveillance at Los Alamos during 2005," LA-14304 -ENV, September 2006.

3. Los Alamos National Laboratory, "SWEIS Yearbook-2005," LA-UR-06-6020, 2006.

4. U.S. Department of Energy, "Site-Wide Environmental Impact Statement for Continued Operation of the Los Alamos National Laboratory" (available URL:

http://www.lanl.gov/orgs/pa/News/doerelease051198.html), January 1998.

5. R. Sturgeon, "2006 Radioactive Materials Usage Survey for Unmonitored Tier III Point Sources,"

LA-UR-07-3479, 2007.

6. Los Alamos National Laboratory, “Air Quality Reviews,” Laboratory Implementation Requirement 404-10-01.2.

7. U.S. Environmental Protection Agency, Federal Register, Vol. 60, No. 107, June 5, 1995.

8. Frank Marcinowski, Acting Director, Radiation Protection Division, "Criteria to Determine Whether a Leased Facility at Department of Energy (DOE) is Subject to Subpart H,” Office of Radiation and Indoor Air, U.S. Environmental Protection Agency, March 26, 2001.

9 Keith F. Eckerman, Anthony B. Wolbarst, and Allan C. B. Richardson, Federal Guidance Report No. 11, "Limiting Values of Radionuclide Intake and Air Concentration and Dose Conversion Factors for Inhalation, Submersion, and Ingestion,” Office of Radiation Programs, U.S. Environmental Protection Agency, Washington, D.C., 1988.

10. K. F. Eckerman and J. C. Ryman, Federal Guidance Report No. 12, "External Exposures to Radionuclides in Air, Water, and Soil Exposure-to-Dose Coefficients for General Application,” U.S. Environmental Protection Agency, Washington, D.C., 1993.

11. K. F. Eckerman, R.W. Leggett, C.B. Nelson, J.S. Puskin, and A.C.B. Richardson, Federal Guidance Report No. 13, “Cancer Risk Coefficients for Environmental Exposure to Radionuclides," U.S. Environmental Protection Agency, Washington, D.C., 1999.

12. Los Alamos National Laboratory, Ecology and Air Quality Group, "Dose Factors for Non-CAPP88 Radionuclides,” ENV-EAQ-512, 2007.

13. Los Alamos National Laboratory, "Diffuse emissions from TA-53 for CY 2006," ENV-EAQ:07-080, April $18,2006$.

14. U.S. Environmental Protection Agency, "National Emission Standards for Emissions of Radionuclides Other than Radon from Department of Energy Facilities," Code of Federal Regulations, Title 40, Part 61.90, Subpart H, 1989.

15. Bart Eklund, "Measurements of Emission Fluxes from Technical Area 54, Areas G and L," Radian Corporation report, Austin, Texas, 1995. 


\section{LANL Radionuclide Air Emissions Report}

16. Los Alamos National Laboratory, "Performance Assessment and Composite Analysis for Los Alamos National Laboratory Materials Disposal Area G,” LA-UR-97-85, 1997. 
2006 LANL Radionuclide Air Emissions Report 
This report has been reproduced directly from the best available copy. It is available electronically on the Web (http://www.doe.gov/bridge).

Copies are available for sale to U.S. Department of Energy employees and contractors from:

Office of Scientific and Technical Information

P.O. Box 62

Oak Ridge, TN 37831

(865) 576-8401

Copies are available for sale to the public from: National Technical Information Service

U.S. Department of Commerce

5285 Port Royal Road

Springfield, VA 22161

(800) 553-6847 
- Los Alamos NATIONAL LABORATORY

EST.1943 